\title{
Lines in the sand: quantifying the cumulative development footprint in the world's largest remaining temperate woodland
}

\author{
Keren G Raiter ${ }^{1,2} \bullet$ Suzanne M Prober ${ }^{2,1} \bullet$ Richard J Hobbs $^{1} \bullet$ Hugh P Possingham ${ }^{3,4}$ \\ 1 School of Biological Sciences, University of Western Australia, 35 Stirling Hwy Crawley, Perth, WA, 6009, \\ Australia \\ 2 CSIRO Land and Water, Private Bag 5, Wembley, WA, 6913, Australia \\ 3 The Nature Conservancy, 4245 North Fairfax Drive, Suite 100 Arlington, VA 22203, USA \\ 4 School of Biological Sciences, University of Queensland St Lucia, Brisbane, Qld, 4072, Australia
}

\section{Corresponding author}

Keren Raiter, Department of Ecology, Evolution and Behavior, Hebrew University of Jerusalem, Givat Ram, Jerusalem, Israel. Email: keren.raiter@mail.huji.ac.il / keren.raiter@me.com

\section{Citation for this article}

Raiter, K.G., Prober, S.M., Hobbs, R.J., Possingham, H.P., 2017. Lines in the sand: quantifying the cumulative development footprint in the world's largest remaining temperate woodland. Landscape Ecology 32, 19691986. doi.org/10.1007/s10980-017-0558-z

\section{Copyright statement}

(C) 2017. Original research article. This is the accepted author manuscript. The final version is available at Springer at: http://dx.doi.org/10.1007/s10980-017-0558-z. This manuscript version is made available under the CC-BY-NC_ND 4.0 licence https://creativecommons.org/licenses/by-nc-nd/4.0/.

\section{Keywords}

GIS; road ecology; Great Western Woodlands; linear infrastructure; ecological impact assessment; development footprint; cumulative impacts; offsite impacts; indirect impacts. 


\section{Abstract}

\section{Context}

The acceleration of infrastructure development presents many challenges for the mitigation of ecological impacts. The type, extent, and cumulative effects of multiple developments must be quantified to enable mitigation.

\section{Objectives}

We quantified anthropogenic development footprints in a globally significant and relatively intact region. We identified the proportion accounted for by linear infrastructure (e.g. roads) including infrastructure that is currently unmapped; investigated the importance of key landscape drivers; and explored potential ramifications of offsite impacts (edge effects).

\section{Methods}

We quantified direct development footprints of linear and 'hub' infrastructure in the Great Western Woodlands (GWW) in south-western Australia, using digitisation and extrapolation from a stratified random sample of aerial imagery. We used spatial datasets and literature resources to identify predictors of development footprint extent and calculate hypothetical 'edge effect zones'.

\section{Results}

Unmapped linear infrastructure, only detectable through manual digitisation, accounts for the greatest proportion of the direct development footprint. Across the $160,000 \mathrm{~km}^{2} \mathrm{GWW}$, the estimated development footprint is $690 \mathrm{~km}^{2}$, of which $67 \%$ consists of linear infrastructure and the remainder is 'hub' infrastructure. An estimated 150,000 km of linear infrastructure exists in the study area, equating to an average of $\sim 1 \mathrm{~km}$ per $\mathrm{km}^{2}$. Beyond the direct footprint, a further $4,000-55,000 \mathrm{~km}^{2}(3-35 \%$ of the region) lies within edge effect zones.

\section{Conclusions}

This study highlights the pervasiveness of linear infrastructure and hence the importance of managing its cumulative impacts as a key component of landscape conservation. Our methodology can be applied to other relatively intact landscapes worldwide. 


\section{Introduction}

In an era where development of infrastructure in natural environments is accelerating, there is an urgency to understand and minimise the ecological impacts of these developments (e.g. Elmes et al. 2014; Fraser 2014; Karlson and Mortberg 2015; Laurance et al. 2015; Runge et al. 2017; Seiferling et al. 2014). Despite advances towards mitigation, such as the development of extensive impact assessment protocols, our understanding of the cumulative impacts of development is often poor and methods for measuring and quantifying them are not well-developed (Freudenberger et al. 2013; Jaeger 2015; Laurance et al. 2015; Raiter et al. 2014). In particular, roads and other linear infrastructure greatly expand the footprint of human activity but their impacts are frequently disregarded and seldom addressed although they may be farreaching (Goosem 2007; Goosem 2012; Jaeger 2015; Jones et al. 2014).

'Cumulative impact' refers to the collective effects of multiple impacts that may be considered negligible or environmentally acceptable individually, but in sum may be significant and environmentally unacceptable (Canter and Ross 2010; Therivel and Ross 2007). Cumulative impacts are often overlooked in impact evaluations and decision-making regarding environmental conservation due to the difficulty of dealing with numerous impacts often spread extensively over both space and time, and legal limitations in doing so (Raiter et al. 2014; Runge et al. 2017), However, cumulative impacts can lead to so-called 'death by a thousand cuts' (Schneider and Dyer 2006), particularly when systems are pushed beyond ecological thresholds, or ecosystem effects act synergistically (Raiter et al. 2014).

The challenge of quantifying cumulative infrastructure development across large areas is substantial, but essential if these impacts are to be mitigated (Raiter et al. 2014). Comprehensive quantifications of anthropogenic development footprints across whole landscapes or regions are rarely undertaken (Abood et al. 2014; Carranza et al. 2014; Karlson and Mortberg 2015; Suring et al. 1998), and those available are typically restricted only to development associated with a particular industry or activity (Jones et al. 2014; Nellemann and Cameron 1998; Wood et al. 2014). Furthermore, in many cases, quantifying the area directly disturbed by development (hereafter 'development footprint') is particularly challenging as spatial data on development footprints often do not exist or are not comprehensive; this lack of information hampers broadscale impact analyses (Finer et al. 2013).

Geotechnology (also known as geospatial technology), including Geographic Information Systems (GIS) and remote sensing, has been named one of the three 'mega-technologies' of the $21^{\text {st }}$ Century and has had a substantial impact on ecological research in recent decades (Boyd and Foody 2011). Increased availability and use of GIS software and spatial datasets have led to large improvements in our ability to measure and visualise multiple impacts, and can also reveal previously unobserved phenomena, although major issues of data completeness, errors, and interpretation over multiple scales exist (Boyd and Foody 2011; Ferraz et al. 2016).

There has been a growing number of papers that try to quantify the impact of infrastructure over broad areas. Johnson et al. (2005), Finer et al. (2008), Baynard (2011), and Mjachina et al. (2014) quantified development footprints of oil and gas, diamond, and other mineral exploration and extraction activities. However, these studies all relied heavily on existing spatial data, (e.g. provided by government sources), and/or data based on course-resolution imagery, which may not have included the full development footprint.

Indeed, Hawbaker and Radeloff (2004) argue that road impacts are generally underestimated because available data sources often do not include complete road networks, leading to false assumptions about the ecological effects of roads. They digitised road networks from aerial imagery, and found significantly higher road densities for northern Wisconsin compared to estimates based on three other road data sources. Several other studies have incorporated digitisation based on remotely sensed imagery to quantify road network growth (Ahmed et al. 2013), identify transport network drivers (Westcott and Andrew 2015), reveal 
illicit mining activities (Elmes et al. 2014), and compare the footprints of oil exploration and production companies (Baynard 2011), although these have often been at limited scales and/or resolutions.

Previous quantifications of cumulative development impacts have rarely accounted for offsite impacts, including the ecological effects of developments that extend into surrounding landscapes (hereafter 'edge effects'; Raiter et al. 2014). Edge effects can be considerably larger than the direct development footprint of a development (Jaeger 2015). For example, the majority of the woodland caribou's habitat in the boreal forests of western Canada has ceased to be suitable, although only a small proportion of it is directly disturbed by development. This is due to the edge effects of roads and wells for oil sand extraction which are frequently spaced 1-2 km apart: caribou avoid such infrastructure by approximately $1 \mathrm{~km}$ (Schneider and Dyer 2006). Edge effect zones (also road effect zones), defined as the area over which the ecological impacts of anthropogenic disturbances extend into the adjacent landscape, provide a useful conceptual framework for quantifying edge effects (Forman et al. 2003; van der Ree et al. 2015a), but their application at landscapescales has been limited (e.g. Liu et al. 2008).

We developed an approach to quantifying the total development footprint and edge effects in the globally significant Great Western Woodlands of south-western Australia, to address the need for better quantification of the impacts of extensive developments. The Great Western Woodlands (GWW) is a very large $\left(160,000 \mathrm{~km}^{2}\right)$, relatively intact area, and is also a mineral-rich region impacted by extensive mineral exploration and extraction activities as well as pastoral grazing. The ecological impacts of these activities have never been quantified on a regional scale. We use the term 'relatively intact' to refer to an area that is large and dominated by natural ecosystems and processes (adapted from Caro et al. (2012)), although degrading processes may exist within it. The relative nature of the term connotes a comparison not only with wholly intact landscapes, but also with the other alternative: highly modified landscapes in which ecological processes have become highly modified.

To explore the extent and nature of ecological impacts associated with human developments, we manually digitised development footprints within stratified random samples of the GWW. We assessed the proportion of the development footprint that comprises linear infrastructure, and the proportion of these that is unmapped. We also investigated the potential drivers of development extent (e.g. mining activity, pastoral grazing) and other associated landscape factors (including proximity to towns and edge of agricultural area, vegetation type and conservation tenure; see Appendix 1), and quantified linear infrastructure densities and edge effect zones under various scenarios. This study is unique in quantifying and characterising direct and offsite ecological impacts of development, while accounting for direct development footprints; both mapped and unmapped. The methodology presented here can be applied to other relatively intact landscapes to improve cumulative impacts evaluations and inform mitigation.

\section{Methods}

\section{Study area}

The $160,000 \mathrm{~km}^{2}$ Great Western Woodlands (GWW) in south-western Australia is the largest and most intact area of temperate woodland remaining on Earth, straddling a transition between a Mediterranean-climate to the south-west and a semi-arid climate to the north-east (Figure 1; Judd et al. 2008; Prober et al. 2012). Mediterranean-climate regions world wide - in Australia, the Americas, Africa, and the Mediterranean Basin - have all experienced intense development pressure for agriculture and urbanization (Underwood et al. 2009). In contrast, the ecosystems of the GWW remain largely intact and naturally functioning (Prober et al. 2012). 


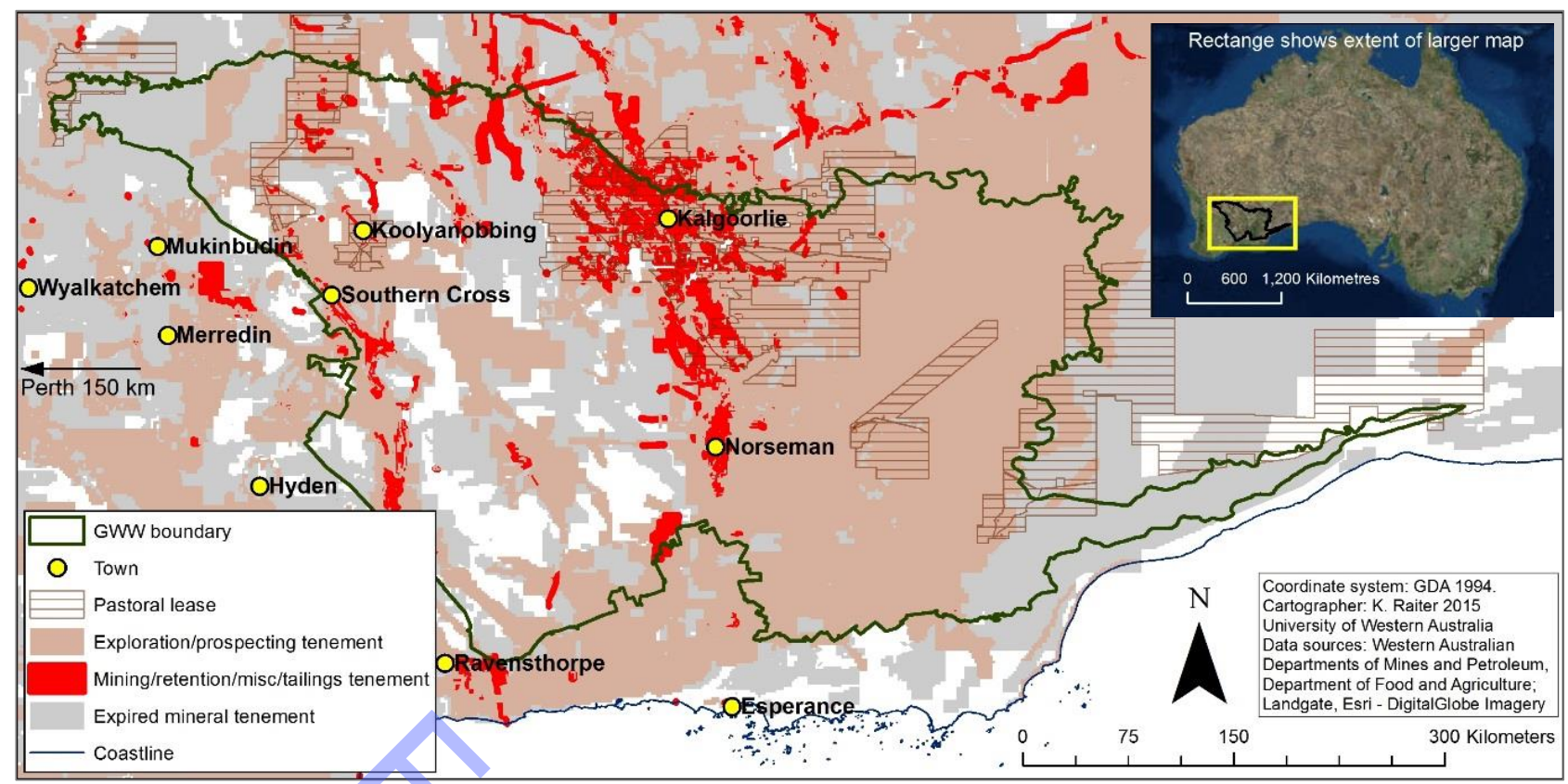

Figure 1: Study area showing towns, mineral tenements and pastoral leases. The Wheatbelt lies to the west and south of the Great Western Woodlands.

The GWW comprises a mosaic of habitats including woodland, shrubland, mallee, salt lakes, rocky outcrops, and banded ironstone formations and has globally significant levels of flora and fauna diversity including over one sixth of Australia's vascular plant species (Judd et al. 2008). The region also comprises a significant refuge for many species that have declined or become locally extinct elsewhere (such as the adjacent Mediterranean-climate wheatbelt), and holds a significant component of Australia's green carbon stocks (Berry et al. 2010). As such, it has been identified as being of international significance (Department of Environment and Conservation 2010; Evans et al. 2015; Prober et al. 2012), and as a continental and global priority for conservation (Booth and Traill 2008; Watson et al. 2008).

Although it escaped widespread clearing for intensive agriculture, approximately a third of the GWW is under pastoral tenure for sheep or cattle grazing. The region also overlies the Late Archaean granite-greenstone terranes of the Eastern Yilgarn Craton; geological formations which contain high-quality mineral deposits including gold, nickel, iron ore, silver, copper, and cobalt. Since gold was discovered in 1888, most of the region has experienced some mineral exploration and prospecting, with mineral extraction activities concentrated predominantly along greenstone belts. There is a long history of mining activity in the region and, despite global fluctuations in commodity prices, the future is likely to see more, with record levels of both exploration and mining applications lodged in recent years (Department of Mines and Petroleum 2015).

\section{Spatial and data analyses}

\section{Direct development footprint}

All spatial and numerical datasets produced and analysed in the course of this study are available at https://doi.org/10.4227/05/59893d248decc (Raiter 2017). All spatial analyses were performed in ArcGIS 10.3 and Geospatial Modelling Environment (Version 0.7.4.0; available from www.spatialecology.com), and all data analyses were performed in $\mathrm{R}$ (version 3.2.0, R Core Team 2015). We created a $20 \times 20 \mathrm{~km}$ grid overlying the study area and categorised each grid cell into one of 8 categories made up of four levels of mining activity and a binary indicator for pastoral status (Figure 2). Density of mining projects, calculated using the Minedex layer provided by Department of Mines and Petroleum, was used as a proxy for mining activity level. Pastoral status was based on pastoral datasets provided by Department of Agriculture and Food of Western Australia (DAFWA) and included former pastoral areas that are currently in transition to conservation tenure. 


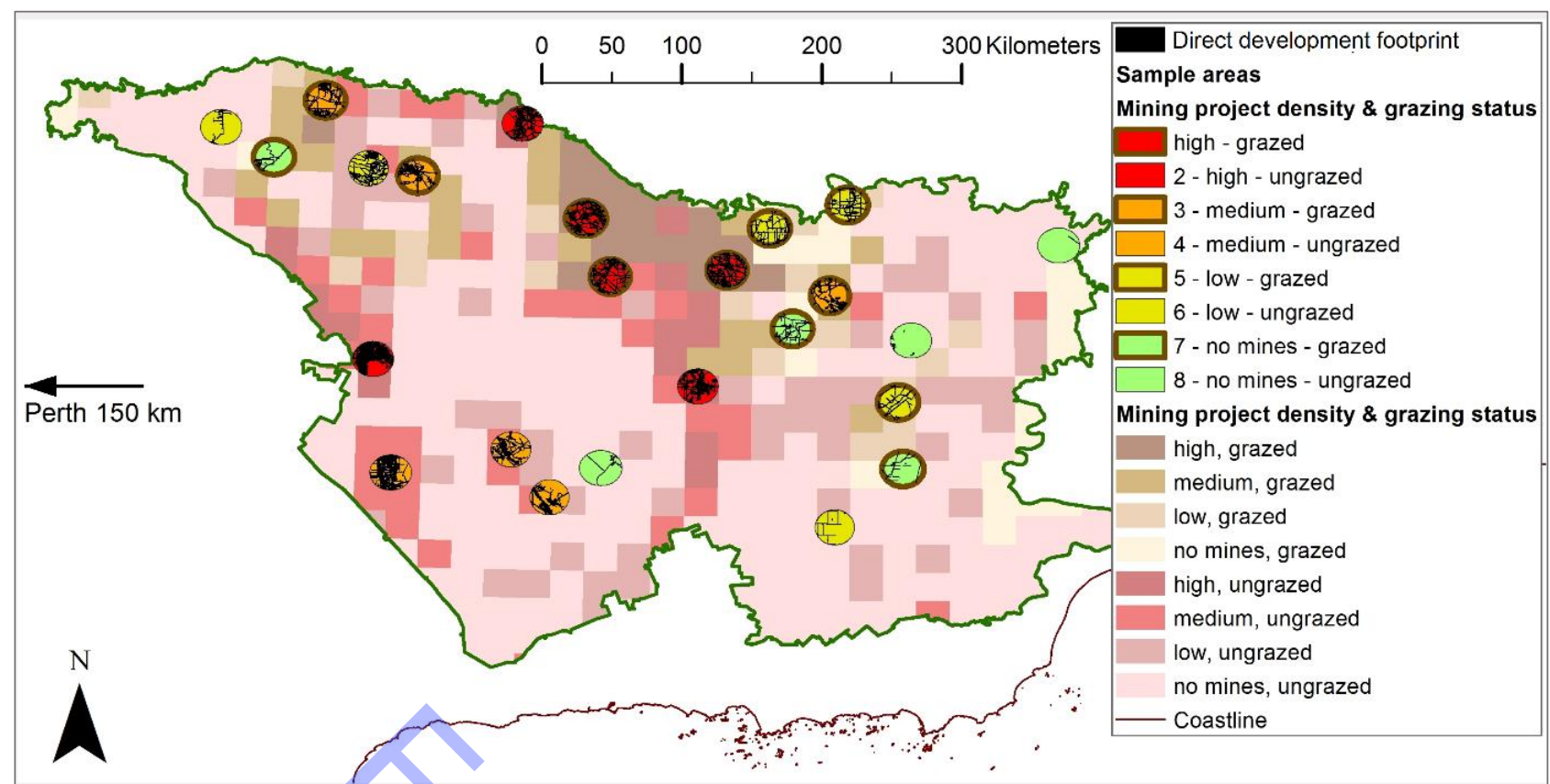

Figure 2: Mining density and pastoral status grid used for selection of sample areas and estimation of disturbance footprints for the whole region. Sample areas and the observed development footprint are also shown.

We used stratified random sampling to distribute 24 circular sample areas, each $25 \mathrm{~km}$ in diameter, among the 8 mining and pastoral categories. We used circular sample areas to minimise the edge-to-area ratio of the sample areas and therefore maximise the extent to which the sample areas reflected the category represented rather than the adjacent landscape. Circular sample areas also helped to reduce sampling bias which may occur due to coincidental alignment of the sample area boundary with tenure boundaries or roads, and better reflect the landscape as a whole. Sample area diameters of $25 \mathrm{~km}$ were selected to balance capture of the landscape variability with logistics of digitisation. The sample area locations were all randomly selected within each category, except for two which were placed in areas of particular interest to conservation needs in the region (Lake Cronin and Helena-Aurora Range). Grid cells with towns were excluded, as were some grid cells to the far east where high-resolution imagery was not available. In total, the sample areas represented $11,729 \mathrm{~km}^{2}(7.34 \%)$ of the GWW by area.

We created a spatial layer containing all mapped linear infrastructure based on 23 unique datasets obtained from Department of Parks and Wildlife (DPaW), DAFWA, Landgate, and Geosciences Australia. Mapped linear infrastructure elements were classified as 'railway', 'major road', 'paved minor road', 'unpaved road', 'track', 'fence line', 'relegated route' and 'unknown' based on information provided in the source layers. The latter four classifications were merged with 'tracks' for the purposes of this study. No region-wide spatial data for hub infrastructure were available.

KR and a team of volunteers digitised all physical anthropogenic disturbances visible from high-resolution ortho-rectified aerial imagery (orthophotos) that weren't already mapped, for the full extent of each sample area, at an average scale of 1:2000. KR maintained consistency between the digitisation performed by different people by providing every volunteer with identical training in the methodology to be used, close supervision, and close review of all data outputs. Corrections and supplementation of the digitised dataset was performed where necessary by KR.

The orthophoto sets used were provided by Landgate and were the two most recent available for each area, dating between 2003 and 2014, and with 50-140 cm pixel resolution. All unmapped linear infrastructure was classified as 'track'. Mapped features generally matched up with observable features although there were some tracks that were difficult to distinguish, and the locational accuracy of some was low. All features which 
were polygonal (i.e. not linear: e.g. mine pits, waste-rock dumps, dams, homesteads and mine worker camps) were grouped as 'hub' infrastructure. Hub infrastructure was digitised with polygon feature classes by tracing the approximate edge of the disturbance feature. Linear infrastructure was digitised as line features and then both mapped and unmapped linear infrastructure features were converted to polygon features using their average widths in order to calculate the area of their development footprints. To calculate average widths of linear infrastructure features, points were randomly placed along each type of linear infrastructure within each sample area and the width of the linear infrastructure at each random point was measured by zooming in to 1:100 scale. Where there was only one feature per type of linear infrastructure, 5 width measurements were taken; otherwise between 20 and 50 width measurements were taken per feature type per sample area, amounting to 1237 width measurements in total. To determine whether there was a significant difference between mapped and unmapped tracks, their widths were modelled using linear mixed models, with mining activity level and pastoral status as possible fixed factors and sample area as the random factor (Appendix 2).

\section{Ground-truthing}

We ground-truthed a selection of all types of mapped and digitised infrastructure, as well as areas in which no disturbance features were observed from orthophotos along a travel route of approximately $500 \mathrm{~km}$. The travel route included travel along some unmapped tracks and approximately $100 \mathrm{~km}$ of walking off-road. Extensive fieldwork in the study area (for related studies) gave KR further experience in assessing disturbance features based on orthophotos.

\section{Region-wide analysis of development footprint}

For each sample area we calculated mining project density, distances to the nearest town and to the edge of the wheatbelt (Figure 1), and total development footprint. The wheatbelt is an agricultural area with a much higher population density relative to that of the GWW and the areas that lie to the north and east of the GWW. In addition to proximity to towns, proximity to the wheatbelt may act as a proxy for human accessibility' and therefore be associated with increased disturbance (e.g. for recreational use, prospecting, sandalwood harvesting, as well as mineral exploration for explorers that prefer to target more 'accessible' resources that might be therefore cheaper to transport to ports or markets).

To explore potential drivers of development extent, we modelled footprint area (square-root transformed; response variable) against mining project density (log-transformed), pastoral status, and shortest distance to the wheatbelt (explanatory variables), using linear models in the 'Ime4' package. We also tested for an interaction between mining project density and pastoral status. Distance to town was excluded due to high collinearity (-0.6) with mining project density, and showed no trend with the model residuals.

We selected the optimal model based on comparison of adjusted $R^{2}$ and Akaike information criterion with a correction for finite sample sizes (AICC) values, both of which indicated the same optimal model. We used the optimal model to estimate the development footprint across the rest of the GWW for each $20 \times 20 \mathrm{~km}$ grid cell. We also estimated linear infrastructure density for the GWW and proportion accounted for by each infrastructure type using average densities and proportions for each infrastructure type and analysis category and extrapolation based on the $20 \times 20 \mathrm{~km}$ grid.

\section{Patch-level predictors of development footprint}

To gain further insights into the effects of other landscape variables, we divided sample areas into polygonal 'patch types', each with a unique combination of the following categorical covariables: pastoral tenure, greenstone lithology, conservation tenure, ironstone formation, schedule 1 area clearing restrictions, environmentally sensitive area designation, vegetation formation, and sample area (Appendix 1). The vegetation formations dataset was created by grouping the vegetation types in the source layer (Table 1). 
Table 1: The vegetation formations used in the patch-level analysis of development footprints

\begin{tabular}{ll}
\hline Vegetation formation & Description \\
\hline bare/rock/lake & $\begin{array}{l}\text { salt lakes, clay pans, lagoons, and rocky outcrops with little or no } \\
\text { vegetation cover }\end{array}$ \\
broombush thicket & $\begin{array}{l}\text { thicket dominated by Acacia, Allocasuarina and Melaleuca spp; } \\
\text { often growing together in an alliance }\end{array}$ \\
mallee & low, multi-stemmed eucalypts stands generally dominated by \\
& Eucalyptus eremophila and E. redunca \\
mulga & $\begin{array}{l}\text { low, sparse woodland dominated by Acacia aneura complex and } \\
\text { associated species. }\end{array}$ \\
shrubland & heath, shrub, and grass lands mainly dominated by Acacia spp., \\
as well as species belonging to the Proteaceae and Myrtaceae \\
families. \\
succulent steppe
\end{tabular}

For each patch type ( $n=261$ ), we calculated the following attributes: number of mining projects, number of dead mineral tenements, sum of duration of all live and dead tenements, type of tenements (exploration/prospecting tenement, mining and related activities tenement, none), primary target commodity (gold, nickel, iron-ore, other), distance to wheatbelt, and distance to nearest town. Presence of a mining tenement overrode the presence of any exploration tenements.

We modelled the proportion area under development footprint (logit transformed) as a function of the variables listed above using linear mixed models in ' $n$ lme' package. The logit function is the inverse of the sigmoidal logistic function, which is bound by 0 and 1 , making it effective for transforming skewed proportional data into a model-ready distribution. Where variables were collinear $(r>0.6)$ they were alternated to identify the most significant variable to include. The top-ranking model was selected from 4096 models including the global model and all possible subsets with an information-theoretic approach using AlCc, in 'MuMin' package (Barton 2015).

\section{Edge effect zones}

We created zones around the direct development footprint representing offsite impact risk for each type of infrastructure, using a hypothesized set of risk buffers. These were based on edge effect distances reported in the literature for species and processes from around the world, as species-specific data for the GWW was not available (Appendix 3). This methodology is an adaptation of the approach presented by Liu et al. (2008), and although it represents a simplistic generalisation, it offers a useful starting point for calculating the likely extent of ecological impacts outside of the direct development footprint. Edge effects include reduced habitat quality adjacent to disturbed areas; groundwater contamination; chemical, dust, sound and light pollution and changes; introduction of invasive organisms; and barriers to ecological flows and processes (Beyer et al. 2014; Karlson and Mortberg 2015; Roche and Mudd 2014; Tyler et al. 2016). We buffered the various infrastructure features by different widths to represent edge effect risk under conservative, medium, 
and maximal scenarios and plotted the proportion of the landscape within these zones by mining project density for each scenario (Appendix 3; Table A3.1).

\section{Results}

Linear infrastructure dominated the development footprint in all except grazed areas with the highest mining project densities. Overall, linear infrastructure is estimated to account for $67 \%$ of the total direct development footprint across the GWW outside of towns, with the remainder comprising (mining and pastoral) hub infrastructure (Figure 3 and Table 2). Linear infrastructure that was previously unmapped and was quantified by digitisation represented $51 \%$ of the total development footprint of linear infrastructure (i.e. by area), and $52 \%$ of the total length of linear infrastructure projected for the GWW. Tracks made up the vast majority of all linear infrastructure, and most were not mapped in any of the 23 unique datasets compiled, representing all existing spatial data for linear infrastructure in the region of which we are aware. The total direct development footprint for the GWW is estimated to be $690 \mathrm{~km}^{2}$ (s.e. $588-814 \mathrm{~km}^{2}$ ) or $0.43 \%$ of the total land area of the region. This amounts to an estimated total of $\sim 150,000 \mathrm{~km}$ of linear infrastructure in the region (four times around the planet), with linear infrastructure densities ranging from $0.1 \mathrm{~km} \mathrm{~km}^{-2}$ in ungrazed areas with no registered mining projects, to $3.7 \mathrm{~km} \mathrm{~km}^{-2}$ in ungrazed areas with the highest density of mining projects.

Mapped tracks were on average $\sim 1 \mathrm{~m}$ wider $(\mathrm{p}<0.0001)$ than unmapped tracks, and the second top-ranked model also indicated a positive effect of pastoral status on track width, with tracks in pastoral areas on average $\sim 0.6 \mathrm{~m}$ wider than tracks in ungrazed areas (Appendix 2).

\section{Ground truthing}

All of the mapped linear infrastructure was able to be confirmed at the locations where we performed ground truthing, although there were three mapped tracks that had been blocked and/or had become overgrown. Out of 134 points where tracks had been digitised using orthophotos, we were able to confirm the presence of 130, although similar to the mapped tracks, some had been blocked or become overgrown, and some had also been ripped to encourage regeneration. In some of the cases where the presence of a digitised track could not be confirmed, it was noted that a fire had passed through the area since the orthophoto was taken, as evidenced by young, regenerating vegetation; thus it was possible that a previously-existing track had become undetectable. In addition, we recorded 79 locations where we observed tracks on the ground although they were not visible in orthophotos; these may have been established more recently than the available orthophoto for that area, or in some cases they may have been difficult to discern from orthophotos due to the presence of a tree canopy.

\section{Region-wide analysis of development footprint}

The region-wide modelling of development footprint found strong positive effects of mining project density and pastoralism, as well as a highly significant negative interaction between the two (adjusted $R^{2}=0.85 ; p$ $<0.001$; Figure 4; Table 3). At low mining project densities, development footprints are more extensive in pastoral areas, but at high mining project densities, pastoral areas are relatively less developed than nonpastoral areas, on average. There were no other top-ranking models (defined as having a difference in AICc from the optimal model of $<2$ ). 


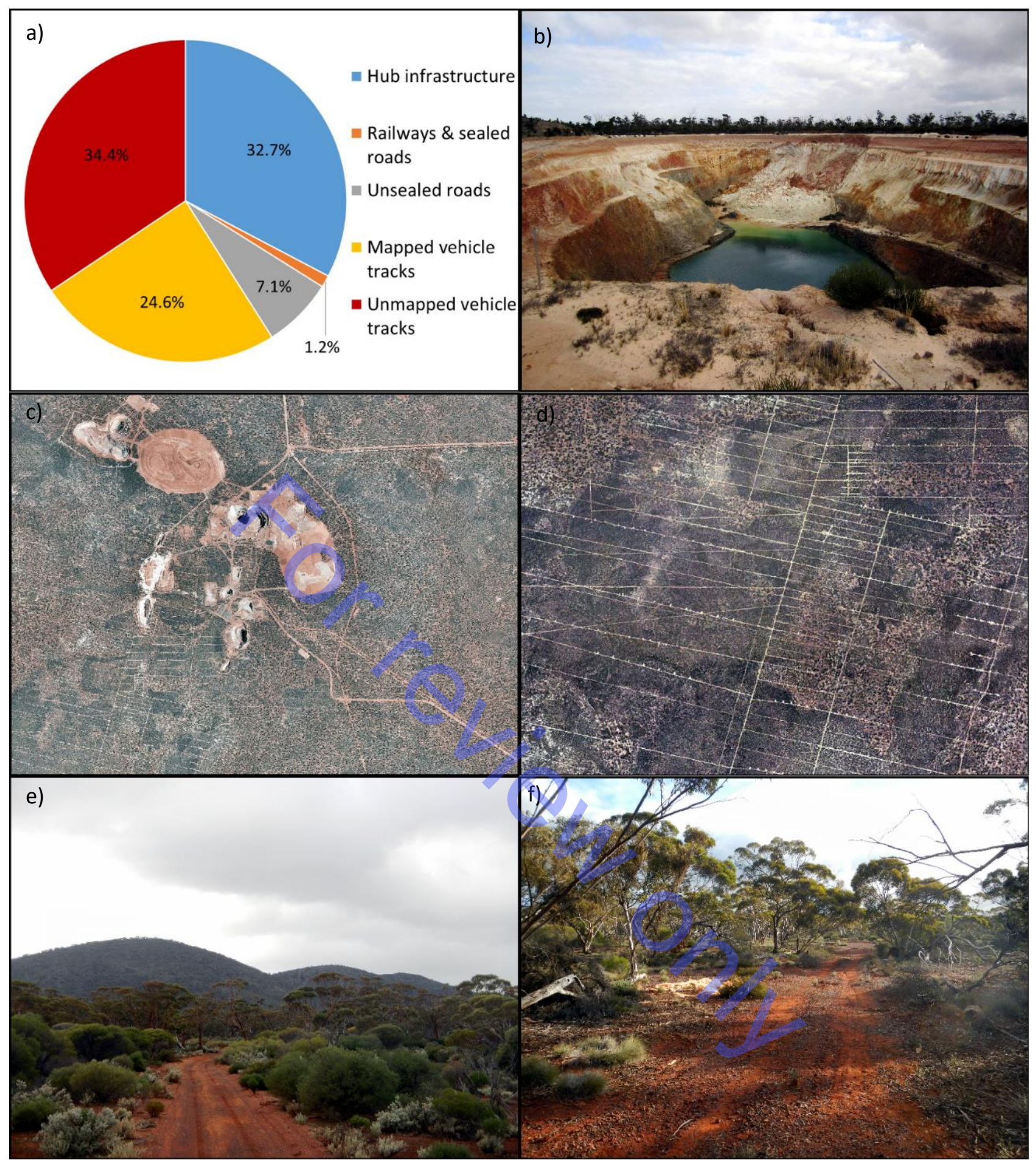

Figure 3: Contribution of different anthropogenic disturbance types to total direct development footprint, with some examples. a) Contribution of different types of linear infrastructure to total footprint. b) An example of 'hub' infrastructure: an abandoned gold mine. c) Aerial view showing both hub and linear infrastructure of a mine and associated exploration grids. d) Aerial view of exploration grids passing through shrubland and woodland vegetation, the white dots are drill pads. e) A mapped track leading to Helena-Aurora Range, one of the banded ironstone formations currently being developed for mining. The track was probably initially built for mineral exploration purposes and is now used by miners, conservation agencies, and tourists. f) A ground-truthed unmapped track with abandoned exploration drilling sample bags to the left. An abandoned hydrocarbon drum was found further along this track. 
Table 2: Estimated development footprint and linear infrastructure density for the Great Western Woodlands

\begin{tabular}{|c|c|c|c|c|c|c|c|c|}
\hline $\begin{array}{l}\text { category } \\
\text { of mining } \\
\text { intensity } \\
\text { and } \\
\text { pastoral } \\
\text { status }\end{array}$ & $\begin{array}{l}\text { area of } \\
\text { category } \\
\left(\mathrm{km}^{2}\right)^{\mathrm{a}}\end{array}$ & $\begin{array}{l}\text { sampled } \\
\text { area of } \\
\text { category } \\
\left(\mathrm{km}^{2}\right)\end{array}$ & $\begin{array}{l}\text { Projected }^{\mathrm{b}} \\
\text { footprint of } \\
\text { all hub inf. } \\
\left(\mathrm{km}^{2}\right)\end{array}$ & $\begin{array}{l}\text { projected }^{b} \\
\text { footprint of } \\
\text { all linear } \\
\text { inf. }\left(\mathrm{km}^{2}\right)\end{array}$ & $\begin{array}{l}\text { total } \\
\text { projected } \\
\text { footprint } \\
\left(\mathrm{km}^{2}\right)\end{array}$ & $\begin{array}{l}\text { total length } \\
\text { of linear } \\
\text { inf. } \\
\text { observed } \\
\text { within } \\
\text { sample } \\
\text { areas (km) }\end{array}$ & $\begin{array}{l}\text { projected }^{d} \\
\text { total length } \\
\text { of linear } \\
\text { inf. }(\mathrm{km})\end{array}$ & $\begin{array}{l}\text { estimated }^{d} \\
\text { average } \\
\text { linear inf. } \\
\text { density for } \\
\text { category (km } \\
\text { km-2 }^{-2}\end{array}$ \\
\hline $\begin{array}{l}\text { high, } \\
\text { grazed }\end{array}$ & 7836 & 1453 & 65.8 & 64.4 & 130.2 & 4449 & 23999 & 3.06 \\
\hline $\begin{array}{l}\text { high, } \\
\text { ungrazed }\end{array}$ & 6525 & 1478 & 96.9 & 89.3 & 186.2 & 5478 & 24184 & 3.71 \\
\hline $\begin{array}{l}\text { medium, } \\
\text { grazed }\end{array}$ & 10564 & 1445 & 27.0 & 76.3 & 103.2 & 2482 & 18142 & 1.72 \\
\hline $\begin{array}{l}\text { medium, } \\
\text { ungrazed }\end{array}$ & 14419 & 1435 & 24.7 & 121.7 & 146.3 & 4067 & 40863 & 2.83 \\
\hline $\begin{array}{l}\text { low, } \\
\text { grazed }\end{array}$ & 8093 & 1478 & 0.39 & 39.7 & 40.0 & 1567 & 8584 & 1.06 \\
\hline $\begin{array}{l}\text { low, } \\
\text { ungrazed }\end{array}$ & 22979 & 1445 & & 51.9 & 60.1 & 1239 & 19708 & 0.86 \\
\hline $\begin{array}{l}\text { no mines, } \\
\text { grazed }\end{array}$ & 8786 & 1486 & & 18.0 & 18.9 & 921 & 5449 & 0.62 \\
\hline $\begin{array}{l}\text { no mines, } \\
\text { ungrazed }\end{array}$ & 80526 & 1510 & 0 & & 3.5 & 167 & 8889 & 0.11 \\
\hline $\begin{array}{l}\text { Whole } \\
\text { GWW }\end{array}$ & 159729 & 11729 & 223.9 & 4.7 & 688.6 & 20370 & 149820 & 1.07 \\
\hline
\end{tabular}

a based on $20 \times 20 \mathrm{~km}$ grid

$\mathrm{b}$ calculated using region-wide model results and observed proportions for each sampling category applied to a $20 \mathrm{x}$ $20 \mathrm{~km}$ grid

c calculated using region-wide model results applied to $20 \times 20 \mathrm{~km}$ grid.

$\mathrm{d}$ calculated by applying the average observed for each analysis category to the area each category comprises within the Great Western Woodlands

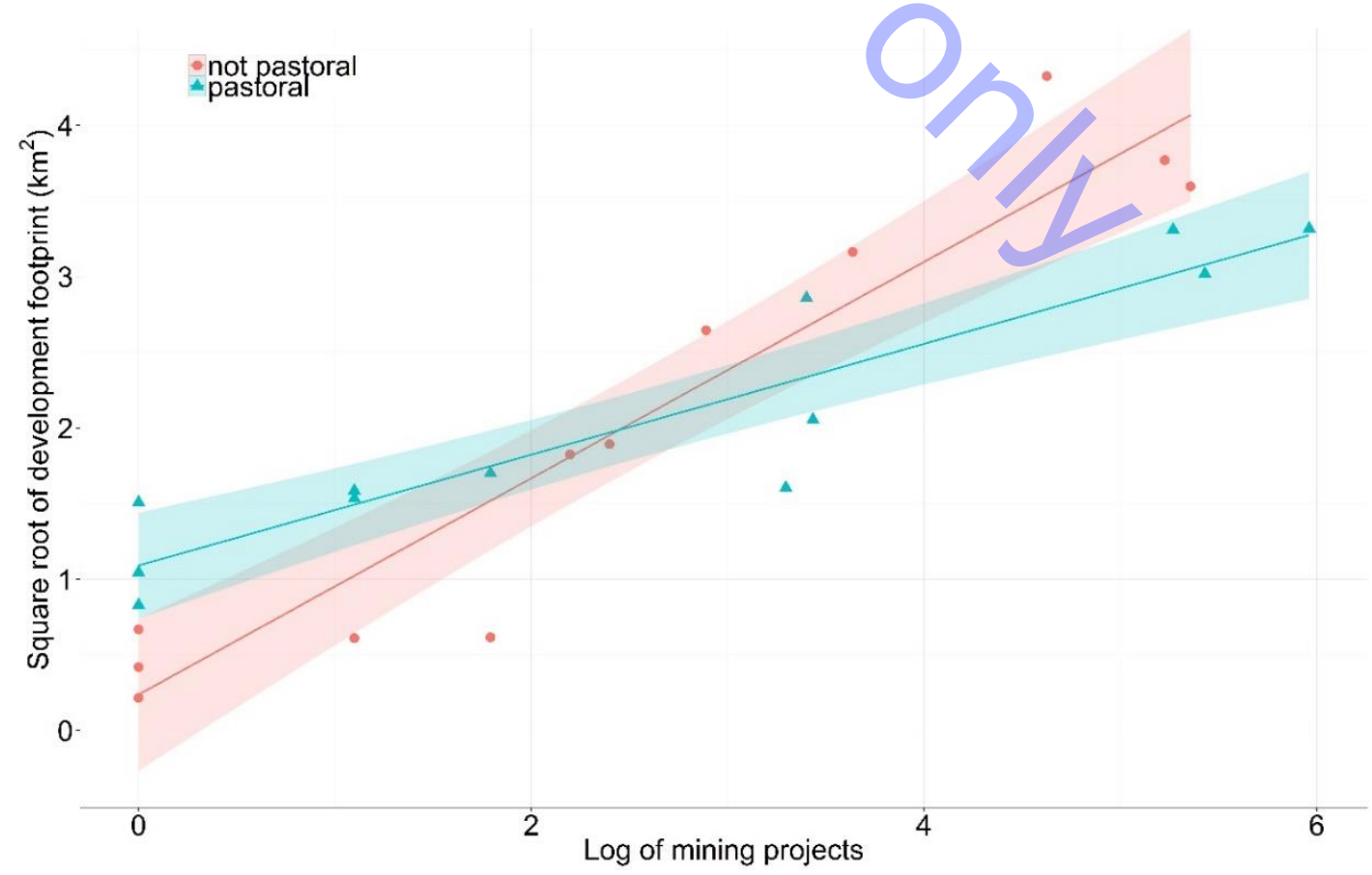

Figure 4: Interacting effects of mining and pastoral tenure on development footprint. The points show the square root of area under the development footprint for each sample area, and the lines indicate the relationship modelled by a linear mixed model, with shading indicating standard error intervals. 
Table 3: Relationships of development footprint to predictor variables in the optimal linear model for the region-wide analysis. There were no other models with AICc values within 2 of the AICc value of the optimal model.

\begin{tabular}{|c|c|c|c|c|c|}
\hline $\begin{array}{l}\text { Response } \\
\text { variable }\end{array}$ & $\begin{array}{l}\text { Mining density } \\
\text { mean estimated } \\
\text { effect }^{\mathrm{a}}\end{array}$ & $\begin{array}{l}\text { Pastoral status } \\
\text { mean estimated } \\
\text { effect }\end{array}$ & $\begin{array}{l}\text { Mean estimated effect of } \\
\text { mining-pastoral } \\
\text { interaction }\end{array}$ & $\begin{array}{l}\text { Adjusted } \\
\mathbf{R}^{2}\end{array}$ & AICc \\
\hline $\begin{array}{l}\text { Development } \\
\text { footprint }^{\text {b }}\end{array}$ & 0.62 & 0.20 & -0.30 & 0.8543 & 35.88 \\
\hline
\end{tabular}

a log-transformed to remove skew in the data distribution.

b square-root transformed to remove skew in distribution.

\section{Patch-level predictors of development footprint}

The patch-level analysis allowed consideration of the effect of more covariates, and analysis at a finer scale. The optimal model for predicting development footprints at the patch level was:

$$
\begin{aligned}
\text { optimal. } d p= & \text { lme }(\text { l.dev.ftp } \sim \text { lntyrs }+ \text { tnkm }+* \text { greenstone }+* \text { esa }+* \text { pastoral }+ \\
& \left.* \text { cons_tenure }, \text { random }=S A_{-} \text {number }\right)
\end{aligned}
$$

where 'optimal.dp' is the final linear mixed effects model for predicting development footprints at the patchlevel; I.dev.ftp is the logit-transformed percent of area under the development footprint, with 0.001 added to allow the logit transformation; Intyrs indicated the natural logarithm of the total number of years during which mineral tenements have applied to the patch; tnkm is the distance to the nearest town; greenstone indicated greenstone lithology; esa indicates the presence or otherwise of environmentally sensitive area clearing regulations; pastoral indicates pastoral tenure or otherwise; and cons_tenure refers to the presence and type of conservation tenure of the patch. The identity of the sample area, 'SA-number' was included as the random factor. Asterisks indicate categorical variables. The AICC value for the optimal model was 639.1; there were no other models with AICc values within 2 of this value.

The patch-level analysis indicated that development increases with tenement duration (i.e. mining activity over time) and decreased with distance from towns (Figure 5). The analysis also indicated a positive association between greenstone lithology and disturbance, as well as the presence of 'environmentally sensitive area' clearing regulations (potentially a perverse effect). The analysis didn't include an interaction between tenement duration (the proxy for mining activity) and pastoral tenure, and the final model reflected the negative relationship between pastoral status and development at relatively high mining activity seen in the region-wide analysis. For conservation tenure, development footprints were greatest in ex-leased lands and lowest in gazetted conservation reserves (excluding Class-A reserves which were the second-least disturbed).

\section{Edge effect zones}

The total area estimated to be at risk of edge effects varied depending on the definition of the buffer around anthropogenic development features and the extent of the development footprint (Figure 6). The calculated proportion of the entire GWW within edge effect zones varied from $\sim 3 \%$ under the conservative scenario to $\sim 35 \%$ under the maximal scenario (Table 4). Within the range of development footprints observed in this study, the proportion of a landscape that lies within edge effect zones increases hyperbolically with the number of mining projects, and approaches $100 \%$ in the maximal scenario, $60 \%$ in the moderate scenario, and $\sim 20 \%$ under the conservative scenario (Appendix 3, Figure A3.1). 

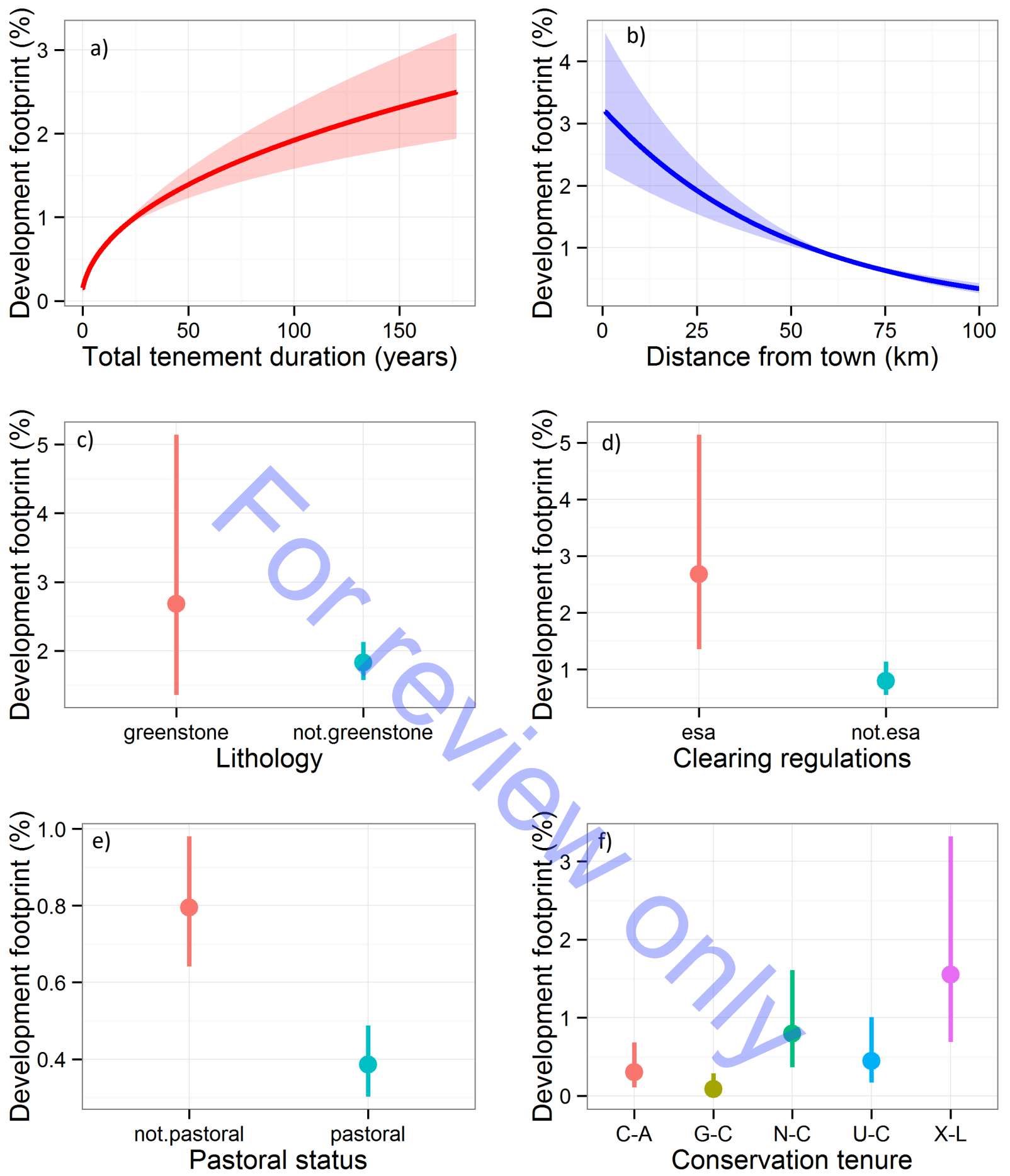

Abbreviations: Conservation tenure: $\mathrm{C}-\mathrm{A}=$ Class-A; $\mathrm{G}-\mathrm{C}=$ gazetted conservation other than Class-A; N$C=$ not conservation tenure; $U-C=$ unofficial conservation tenure; $X-L=$ ex-leasehold land, currently pending conservation registration. Clearing regulations: esa= Declared Environmentally Sensitive Area under section 51B of the Environmental Protection Act 1986.

Figure 5: Predictors of development footprint from patch-level analysis, showing variation for the selected variable when all other variables are held at their mean value or mode. In a) and b), solid lines show predicted means and shading represents standard error; in c) to f), predicted means are indicated by points and lines show standard error range. 
a) high mining intensity; pastoral

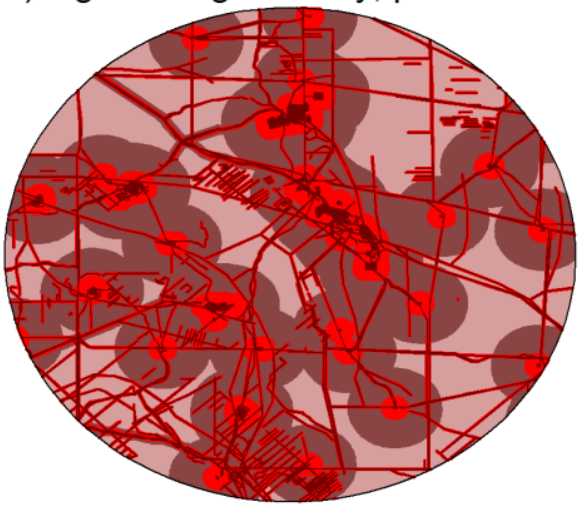

c) medium mining intensity; pastoral

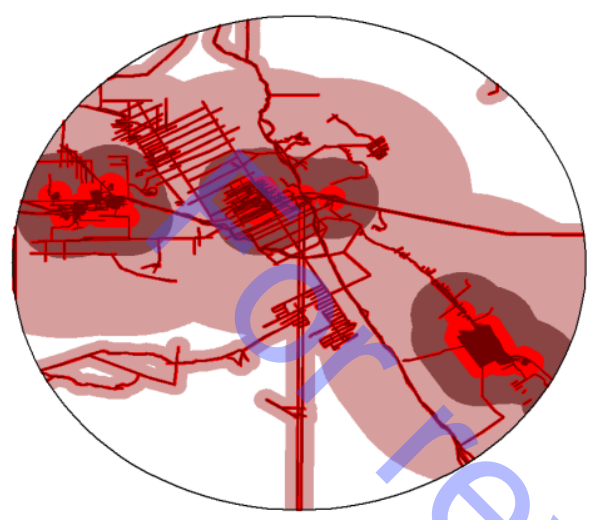

e) low mining intensity; pastoral

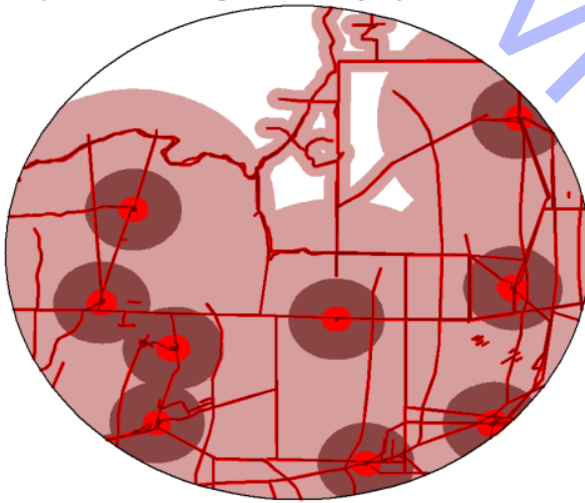

g) no mining projects; pastoral

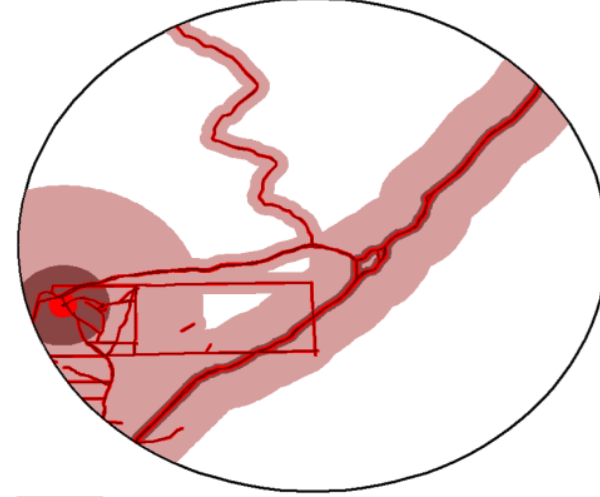

Direct development footprint

Offsite impacts: conservative scenario b) high intensity mining, not pastoral

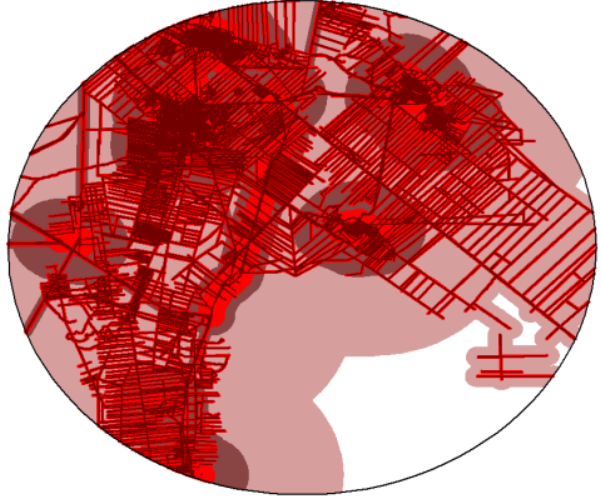

d) medium mining intensity; not pastoral

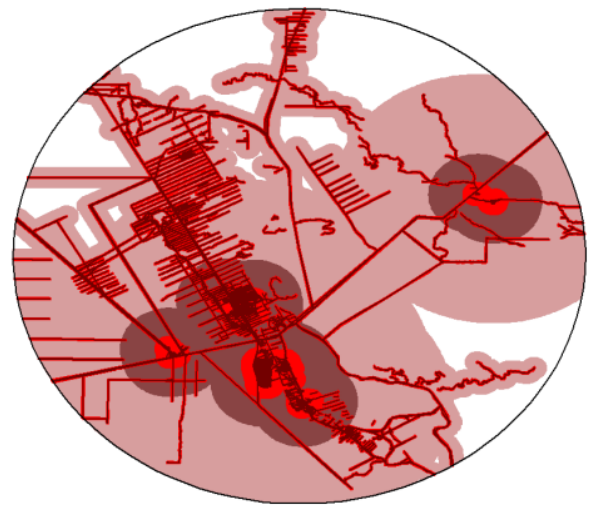

f) low mining intensity; not pastoral

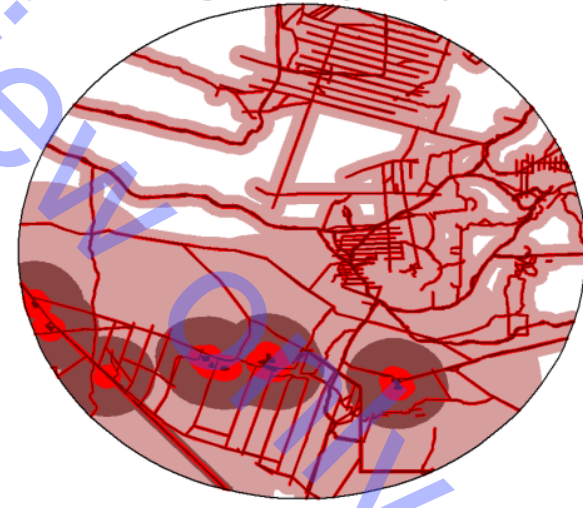

h) no mining projects; not pastoral

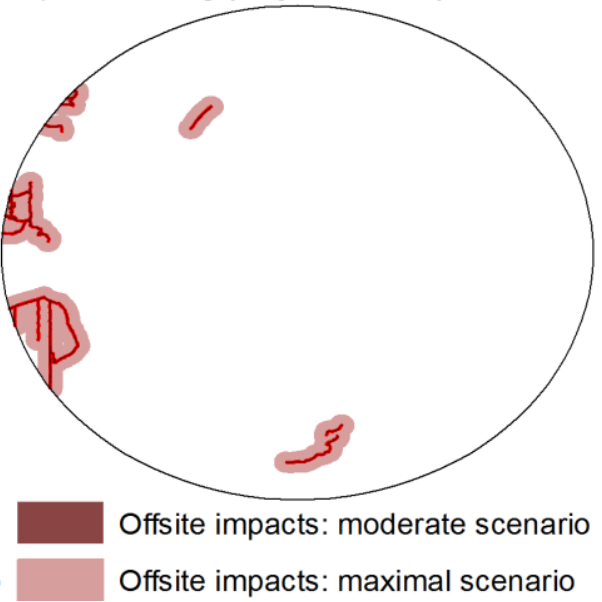

Figure 6: Examples of sample areas from each analysis category showing direct development footprints and areas within edge effect zones for the conservative, moderate, and maximal scenarios. 
Table 4: Areas calculated as falling within edge effect zones for each scenario

\begin{tabular}{|c|c|c|c|c|c|c|c|}
\hline Scenario & $\begin{array}{l}\text { Buffer } \\
\text { around } \\
\text { tracks } \\
(\mathrm{m})\end{array}$ & $\begin{array}{c}\text { Buffer } \\
\text { around } \\
\text { unpaved } \\
\text { roads } \\
(\mathbf{m})\end{array}$ & $\begin{array}{l}\text { Buffer } \\
\text { around } \\
\text { paved } \\
\text { roads } \\
\text { and } \\
\text { railways } \\
\text { (m) }\end{array}$ & $\begin{array}{c}\text { Buffer } \\
\text { around hub } \\
\text { infrastructure } \\
\text { (m) }\end{array}$ & $\begin{array}{c}\text { Range of } \\
\text { areas } \\
\text { affected per } \\
\text { sample area }^{\text {a }} \\
\left(\mathbf{k m}^{2} \text { out of c. }\right. \\
490 \mathbf{k m}^{2} \\
\text { samples) }\end{array}$ & $\begin{array}{c}\text { Projected } \\
\text { proportion of } \\
\text { GWW affected } \\
\text { ecologically } \\
(\%)\end{array}$ & $\begin{array}{c}\text { Projected } \\
\text { proportion of } \\
\text { GWW affected } \\
\text { ecologically } \\
\text { beyond direct } \\
\text { footprint }^{\mathrm{b}}(\%)\end{array}$ \\
\hline $\begin{array}{l}\text { null scenario: } \\
\text { direct } \\
\text { development } \\
\text { footprint only }\end{array}$ & 0 & 0 & 0 & 0 & $<0.01-18.71$ & 0.43 & 0 \\
\hline $\begin{array}{l}\text { conservative } \\
\text { scenario }\end{array}$ & 10 & 50 & 500 & 500 & $0.26-106.5$ & 3.35 & 2.75 \\
\hline $\begin{array}{l}\text { moderate } \\
\text { scenario }\end{array}$ & 50 & 250 & 1000 & 2000 & $1.08-337.3$ & 12.51 & 11.91 \\
\hline $\begin{array}{l}\text { maximal } \\
\text { scenario }\end{array}$ & 500 & 000 & 6000 & 6000 & $9.73-492.8$ & 35.18 & 34.58 \\
\hline
\end{tabular}

${ }^{\text {a }}$ sample areas average $490 \mathrm{~km}^{2}$

${ }^{\mathrm{b}}$ calculated by mining and pastoral categories on $20 \times 20 \mathrm{~km}$ grid, weighted by relative category representation

\section{Discussion}

This investigation has demonstrated a methodology for quantifying the cumulative impacts of development, in a relatively intact region larger than England, that accounts for previously unmapped anthropogenic disturbances, linear infrastructure, and edge effects: all features that are frequently overlooked in impact evaluations and mitigation strategies. Accounting for such 'enigmatic' impacts is essential for mitigating them, although it is a challenging task (Raiter et al. 2014).

We found that mining-related infrastructure has a substantial direct development footprint that extends far beyond hub infrastructure (e.g. mine pits, processing plants, and mine worker camps). Linear infrastructure, particularly smaller roads and tracks, have often been disregarded in evaluations of environmental impacts (Jaeger 2015; Jones et al. 2014), but in the study area is the dominant component of the development footprint. The high proportion of linear infrastructure, which penetrates even relatively intact landscapes, also results in much more extensive edge effect zones than would otherwise occur if the development footprint was concentrated in hub infrastructure (Jones et al. 2014).

We estimated that the direct development footprint of development infrastructure is $690 \mathrm{~km}^{2}$ across the GWW (total 160,000 $\mathrm{km}^{2}$ ), amounting to $0.4 \%$ of the landscape. This is likely to be an underestimate, given the considerable number of tracks observed on-ground which were not identified by digitisation. Our estimate of the development footprint proportion in the GWW is similar to that associated with linear infrastructure used for historical logging and management and tourist access in the Wet Tropics World Heritage Area (0.5\%; Laurance and Goosem 2008); within the range identified for Venezuela's heavy oil belt by Baynard (2011; 1.7-6\%); and twice that reported for the Ustyurt Plateau in Uzbekistan by Jones et al. (2014; 0.2\%). However, the methodologies varied substantially and the results should not be seen as directly comparable. For example, Laurance and Goosem's (2008) estimate did not include the footprint of 'many unpaved forest roads' and Jones et al. (2014) only considered major infrastructure associated with oil and gas exploration activities that was viewable at a relatively low resolution and excluded 'secondary roads'. As we have seen, vehicle tracks make up the majority of the development footprint in the GWW and it could be expected that the development footprint would be substantially larger for both the Wet Tropics and Ustyurt Plateau if vehicle tracks were included in the equation. 
Our estimate of the total length of linear infrastructure across the GWW $(150,000 \mathrm{~km})$ is high compared to an Australia-wide estimate of 823,217 km (356 $343 \mathrm{~km}$ paved; Lister et al. 2015): our estimate accounts for more than $18 \%$ of the Australia-wide total despite the GWW constituting only $2.1 \%$ of Australia's landmass. Given our finding that the majority of linear infrastructure is unmapped, the incongruity of estimates likely reflects large gaps in the dataset upon which the national estimate is based.

Beyond the direct development footprint, large proportions of landscapes fell within hypothesized edge effect zones along the $\sim 300,000 \mathrm{~km}$ of disturbance edges (up to $100 \%$ of high-mining landscapes under the maximal risk scenario). Zones indicating risk of edge effects offer only a simplistic indication of the possible extent of edge effects, particularly without specific information on edge effects relevant to the local biota, and factors affecting impact intensities. Nevertheless, this work demonstrates that the potential for biodiversity loss caused by extensive development should not be underestimated, even when the direct footprint is relatively small, although the distribution of infrastructure within the landscape is also important (Bernath-Plaisted and Koper 2016; Goosem 2007; Jones et al. 2014).

The $150,000 \mathrm{~km}$ of linear infrastructure estimated for the study area also presents a significant threat of 'internal fragmentation' of remaining continuous habitats, with potential impediments to movements of fauna and flora between habitats on either side (Goosem 2007; Jones et al. 2014), although there is a need for further research on how the infrastructure affects different species groups. Other impacts of linear infrastructure that have been identified for the GWW include concentration of predator activity (K. Raiter unpublished data), effects on the movement of water and soil erosion (K. Raiter unpublished data), and weed invasion (Gosper et al. 2015).

Nevertheless, many forms of linear infrastructure may be more amenable than some forms of hub infrastructure to either active or passive regeneration, with some vehicle tracks observed being somewhat overgrown. In contrast, open-cut mine pits are typically left as open voids after mine completion or abandonment and are likely to remain almost permanent scars in the landscape (Roche and Mudd 2014).

The large proportion of unmapped linear infrastructure, and the unmapped nature of hub infrastructure highlight that available data sources are rarely comprehensive. This can lead to false conclusions about ecological impacts, consistent with Hawbaker and Radeloff (2004). Individual mining companies in the study area are required to provide regulatory agencies with maps of the infrastructure they are seeking approval for, but it is likely that much of the unmapped infrastructure observed was constructed prior to this requirement coming into force. Further, maps that are submitted are generally contained within individual submissions that are often difficult to access and transfer to a useable format. This situation will change in coming years with a shift toward electronic lodgement of spatial data and management of that data in accessible forms by the relevant government department, although such data will only include future approvals and not incorporate substantial historical impacts.

There were a number of factors that were found to significantly predict the extent of development footprints in the Great Western Woodlands. The principal factor was mining activity, indicated in our region-wide analysis by mining project density and in the patch-level analysis by the total duration of mining tenement existing over an area. The extent of the development footprint may also be affected by the type of commodity targeted and associated exploration requirements and extraction methods, but this could not be discerned from the current analysis. Mining and exploration practices have changed over time and the development of GPS technology has allowed exploration to move away from the construction of large exploration grids, with explorers able to more easily avoid large trees and other important features while maintaining positional accuracy. It was not possible in this analysis to compare the effects of different practices over time.

Pastoral grazing was also found to significantly predict development footprints, although the interaction with mining project density in the region-wide analysis demonstrated that its effect can be mixed. At low mining densities, pastoral activity is the dominant land use and predicts more extensive development footprints, 
while it appears that, at high mining densities, pastoralism is associated with smaller footprints. This result was contrary to expectations that the effect would be approximately additive. It may reflect the 'good neighbour policy' and related codes of conduct whereby exploration companies operating within pastoral leases are required to use existing roads where possible and rehabilitate all cleared areas once the exploration is complete (Department of Mines and Petroleum 2013; The Chamber of Mineral and Energy et al. 1999). This finding indicates that there is substantial scope for companies to reduce footprints outside of pastoral leases.

This study does not encompass the ecological impacts of pastoralism which are not associated with the actual infrastructure footprint, but which may cover much larger areas. These impacts include loss of vegetation and microbial crusts due to grazing and trampling; soil erosion; and changes in plant species composition (van Etten 2013), but are beyond the scope of this research.

The patch-level analysis also indicates that proximity to towns is associated with more extensive development footprints, although the exact reasons for this are unknown. Possible explanations include: a) tenements in more accessible places receive the greatest focus for activities that create disturbance; $b$ ) recreation, prospecting, and other activities such as sandalwood harvesting activities (which may drive road or track establishment and clearing) are more likely to occur near towns; c) towns were more likely to be built near large mineral reserves.

\section{Conservation and management implications}

Our finding that linear infrastructure is so pervasive in what remains a relatively intact region, and that the development footprint of the GWW is similar to that of a number of other large, relatively intact areas worldwide (Baynard 2011; Jones et al. 2014; Laurance and Goosem 2008) implies that large areas without roads are becoming increasingly rare. Still, from the perspective of conserving natural habitats and processes, these areas are valuable ecological assets when considered in comparison with highly modified landscapes, and in light of the fact that intact habitats are invariably shrinking worldwide. In order to conserve these areas, comprehensive cumulative impacts assessments must be further developed, applied and maintained, using a GIS and the mitigation hierarchy (avoid, minimise, restore, then offset residual impacts) to guide development decisions and conservation or land-use plans.

In particular, the extensive nature and high edge-to-area ratio of linear infrastructure mean that edge effects are likely to be a large component of the total development impacts in a region, although these impacts are less obvious and can be easily overlooked (Goosem 2007). There is a clear need to better quantify the impacts of linear infrastructure on species and ecological processes in order to improve the accuracy of accounting for these effects (Jaeger 2015). In addition, synergistic effects of development impacts acting in combination with other local and global impacts need to be understood and accounted for, along with means to improve linear infrastructure restoration where appropriate (Raiter et al. 2014). Mitigating the impacts of linear infrastructure networks can be achieved by avoiding the establishment of new infrastructure, consolidating existing linear infrastructure networks, rehabilitating infrastructure that is not essential, and designing and/or retrofitting linear infrastructure to minimise ecological impacts (Bernath-Plaisted and Koper 2016; van der Ree et al. 2015b).

While linear infrastructure can be pervasive, we emphasize that large areas with little infrastructure do remain in the GWW. The ecological impacts of developments that penetrate into undisturbed landscapes (also called greenfield regions) are the greatest of all (Laurance et al. 2015), hence these areas should have the highest priority for protection (all other things being equal), including avoiding infrastructure development, and/or rehabilitating such developments where possible. 


\section{Conclusion}

This study has demonstrated the extensive and largely unmapped nature of anthropogenic disturbance in the world's largest remaining temperate woodland, including the dominance of linear infrastructure and the large potential extent of edge effects. Targeted manual digitisation of direct development footprints in stratified sample areas, combined with spatial analyses and hypothetical edge effect zones gleaned from the literature allowed for a relatively comprehensive quantification and characterisation of actual and potential ecological impacts. Mining activity was identified as the predictor of development footprints. In the current era of global infrastructure proliferation, this study concludes that both direct and offsite ecological impacts of linear infrastructure should be explicitly considered in cumulative impacts assessments and land-use and conservation planning and monitoring.

\section{Acknowledgements}

We gratefully acknowledge support from the Gledden Postgraduate Research Scholarship, the Australian Research Council Centre of Excellence for Environmental Decisions, The Wilderness Society, Gondwana Link, the Natural Environmental Research Program Environmental Decisions Hub, and the Great Western Woodlands Supersite, part of Australia's Terrestrial Ecosystem Research Network. We thank Ophir Levin, Julia Waite, Brad Desmond, and Rachel Omodei for assistance in digitising the unmapped development footprint. We also thank Fiona Westcott for her assistance in ground-truthing, Cliffs Natural Resources for in-kind support in the field, and Amanda Keesing (Gondwana Link), Judith Harvey (DPaW) and Katherine Zdunic (DPaW) for their assistance in supplying spatial information. Ashley Sparrow, Richard Forman, Andrew Bennett, John Bissonette, and two anonymous reviewers provided valuable reviews that improved this manuscript. All fieldwork was carried out under Department of Parks and Wildlife Regulation 4 lawful authority CE003548.

\section{References}

Abood SA, Lee JSH, Burivalova Z, Garcia-Ulloa J, Koh LP (2014) Relative contributions of the logging, fiber, oil palm and mining industries to forest loss in Indonesia. Conservation Letters 8(1):58-67

Ahmed SE, Souza Jr CM, Riberio J, Ewers RM (2013) Temporal patterns of road network development in the Brazilian Amazon. Regional Environmental Change 13(5):927-937

Barton K (2015) MuMIn: Multi-Model Inference. R package version 1.15.1.

Baynard CW (2011) The landscape infrastructure footprint of oil development: Venezuela's heavy oil belt. Ecological Indicators 11(3):789-810

Benítez-López A, Alkemade R, Verweij PA (2010) The impacts of roads and other infrastructure on mammal and bird populations: a meta-analysis. Biological Conservation 143(6):1307-1316

Bernath-Plaisted J, Koper N (2016) Physical footprint of oil and gas infrastructure, not anthropogenic noise, reduces nesting success of some grassland songbirds. Biological Conservation 204, Part B:434-441

Berry S, Keith H, Mackey B, Brookhouse M, Jonson J (2010) Green carbon: the role of natural forests in carbon storage. Part 2. Biomass carbon stocks in the Great Western Woodlands. The Fenner School of Environment and Society, Australian National University E Press, Canberra, Australia

Beyer HL, Gurarie E, Borger L et al (2014) "You shall not pass!": quantifying barrier permeability and proximity avoidance by animals. Journal of Animal Ecology 85(1):43-53

Booth C, Traill B (2008) Conservation of Australia's outback wilderness. Pew Environment Group \& The Nature Conservancy. Wild Australia Program, Sydney

Boyd DS, Foody GM (2011) An overview of recent remote sensing and GIS based research in ecological informatics. Ecological Informatics 6(1):25-36 
Canter L, Ross B (2010) State of practice of cumulative effects assessment and management: the good, the bad and the ugly. Impact Assessment and Project Appraisal 28(4):261-268

Caro TIM, Darwin J, Forrester T, Ledoux-Bloom C, Wells C (2012) Conservation in the Anthropocene. Conservation Biology 26(1):185-188

Carranza T, Balmford A, Kapos V, Manica A (2014) Protected Area Effectiveness in Reducing Conversion in a Rapidly Vanishing Ecosystem: The Brazilian Cerrado. Conservation Letters 7(3):216-223

Czech B (1991) Elk behavior in response to human disturbance at Mount St. Helens National Volcanic Monument. Applied Animal Behaviour Science 29(1):269-277

Department of Environment and Conservation (2010) A biodiversity and cultural conservation strategy for the Great Western Woodlands.

Department of Mines and Petroleum (2013) Prospecting, exploration and mining on pastoral leases. Government of Western Australia, Perth, pp. 1-6

Department of Mines and Petroleum (2015) Record spike in mining and exploration applications for June/July 2015. Environment eNewsletter, 15 edn. Government of Western Australia, Perth, pp. 12

Eigenbrod F, Hecnar S, Fahrig L (2009) Quantifying the road-effect zone: threshold effects of a motorway on anuran populations in Ontario, Canada. Ecology and Society 14(1)

Elmes A, Ipanaque JGY, Rogan J, Cuba N, Bebbington A (2014) Mapping licit and illicit mining activity in the Madre de Dios region of Peru. Remote Sens. Lett. 5(10):882-891

Evans MC, Tulloch Al, Law EA, Raiter KG, Possingham HP, Wilson KA (2015) Clear consideration of costs, condition and conservation benefits yields better planning outcomes. Biological Conservation 191:716-727

Ferraz A, Mallet C, Chehata N (2016) Large-scale road detection in forested mountainous areas using airborne topographic lidar data. Isprs Journal of Photogrammetry and Remote Sensing 112:23-36

Finer M, Jenkins CN, Pimm SL, Keane B, Ross C (2008) Oil and Gas Projects in the Western Amazon: Threats to Wilderness, Biodiversity, and Indigenous Peoples. PloS one 3(8):e2932

Finer M, Jenkins CN, Powers B (2013) Potential of Best Practice to Reduce Impacts from Oil and Gas Projects in the Amazon. PLoS ONE 8(5):e63022

Forman RTT, Sperling D, Bissonette JA et al (2003) Road ecology: science and solutions. Island Press, Washington

Fraser B (2014) Deforestation: carving up the Amazon. Nature 509:418-419

Freudenberger L, Hobson PR, Rupic S et al (2013) Spatial road disturbance index (SPROADI) for conservation planning: a novel landscape index, demonstrated for the State of Brandenburg, Germany. Landscape Ecology 28(7):1353-1369

Goosem M (2007) Fragmentation impacts caused by roads through rainforests. Current Science 93(11):1587

Goosem M (2012) Mitigating the impacts of rainforest roads in Queensland's Wet Tropics: Effective or are further evaluations and new mitigation strategies required? Ecological Management \& Restoration $13(3): 254-258$

Gosper CR, Prober SM, Yates CJ, Scott JK (2015) Combining asset-and species-led alien plant management priorities in the world's most intact Mediterranean-climate landscape. Biodiversity and Conservation 24(11):2789-2807

Hawbaker TJ, Radeloff VC (2004) Roads and landscape pattern in northern Wisconsin based on a comparison of four road data sources. Conservation Biology 18(5):1233-1244

Jaeger JAG (2015) Improving environmental impact assessment and road planning at the landscape scale. In: van der Ree R., Smith D. J., Grilo C. (eds), Handbook of Road Ecology. John Wiley \& Sons, Ltd, Chichester, UK, pp. $32-42$ 
Johnson CJ, Boyce MS, Case RL et al (2005) Cumulative effects of human developments on arctic wildlife. Wildlife Monographs 160:1-36

Jones IL, Bull JW, Milner-Gulland EJ, Esipov AV, Suttle KB (2014) Quantifying habitat impacts of natural gas infrastructure to facilitate biodiversity offsetting. Ecology and Evolution 4(1):79-90

Judd S, Watson JEM, Watson AWT (2008) Diversity of a semi-arid, intact Mediterranean ecosystem in southwest Australia. Web Ecology 8:84-93

Karlson M, Mortberg U (2015) A spatial ecological assessment of fragmentation and disturbance effects of the Swedish road network. Landscape and Urban Planning 134:53-65

Kasworm WF, Manley TL (1990) Road and trail influences on grizzly bears and black bears in northwest Montana. Bears: their biology and management 8:79-84

Laurance WF, Goosem M (2008) Impacts of habitat fragmentation and linear clearings on Australian rainforest biota. In: Stork N. E. andTurton S. M. (eds), Living in a Dynamic Tropical Forest Landscape. Blackwell Publishing, Malden, pp. 295-306

Laurance WF, Peletier-Jellema A, Geenen B et al (2015) Reducing the global environmental impacts of rapid infrastructure expansion. Current Biology 25(7):R259-R262

Lister N-M, Brocki M, Ament R (2015) Integrated adaptive design for wildlife movement under climate change. Frontiers in Ecology and the Environment 13(9):493-502

Liu S, Cui B, Dong S, Yang Z, Yang M, Holt K (2008) Evaluating the influence of road networks on landscape and regional ecological risk--A case study in Lancang River Valley of Southwest China. Ecological Engineering 34(2):91-99

Mahoney SP, Schaefer JA (2002) Hydroelectric development and the disruption of migration in caribou. Biological Conservation 107(2):147-153

Mattson DJ, Knight RR, Blanchard BM (1987) The effects of developments and primary roads on grizzly bear habitat use in Yellowstone National Park, Wyoming. Bears: Their Biology and Management. International Association for Bear Research and Management, Virginia, USA, and Plitvice Lakes, Yugoslavia, pp. 259-273

McCracken SF, Forstner MRJ (2014) Oil road effects on the anuran community of a high canopy tank bromeliad Aechmea zebrina in the Upper Amazon Basin, Ecuador. PLoS ONE 9(1):e85470

Mjachina KV, Baynard CW, Chibilyev AA (2014) Oil and gas development in the Orenburg region of the VolgaUral steppe zone: qualifying and quantifying disturbance regimes. International Journal of Sustainable Development \& World Ecology 21(2):111-126

Nellemann C, Cameron R (1998) Cumulative impacts of an evolving oil-field complex on the distribution of calving caribou. Canadian journal of Zoology 76(8):1425-1430

Prober S, Thiele K, Rundel P et al (2012) Facilitating adaptation of biodiversity to climate change: a conceptual framework applied to the world's largest Mediterranean-climate woodland. Climatic Change 110(1):227-248

R Core Team (2015) R: A Language and Environment for Statistical Computing. R Foundation for Statistical Computing, Vienna, Austria,

Raiter K (2017) Spatial analysis data for 'Lines in the sand: quantifying the cumulative development footprint in the world's largest remaining temperate woodland'. Advanced Ecological Knowledge and Observation System (AKKOS) -Terrestrial Ecosystem Research Network (TERN) Eco-informatics, University of Adelaide, South Australia,

Raiter KG, Possingham HP, Prober SM, Hobbs RJ (2014) Under the radar: mitigating enigmatic ecological impacts. Trends Ecol Evol 29(11):635-644

Roche C, Mudd G (2014) An Overview of Mining and the Environment in Western Australia. In: Brueckner M., Durey A., Mayes R., Pforr C. (eds), Resource Curse or Cure?, CSR, Sustainability, Ethics \& Governance. Springer Berlin Heidelberg, pp. 179-194 
Runge CA, Tulloch AIT, Gordon A, Rhodes JR (2017) Quantifying the conservation gains from shared access to linear infrastructure. Conservation Biology Accepted Author Manuscript.

Schneider R, Dyer S (2006) Death by A Thousand Cuts: The Impacts of In Situ Oil Sands Development on Alberta's Boreal Forest. Oil Sands Fever Series, 1st Edition edn. Canadian Parks and Wilderness Society and The Pembina Institute, Edmonton, pp. 50

Seiferling I, Proulx R, Wirth C (2014) Disentangling the environmental heterogeneity - species diversity relationship along a gradient of human footprint. Ecology 95(8):2084-2095

Suring LH, Barber KR, Schwartz CC, Bailey TN, Shuster WC, Tetreau MD (1998) Analysis of cumulative effects on brown bears on the Kenai Peninsula, Southcentral Alaska. Ursus 10:107-117

The Chamber of Mineral and Energy, Association of Mining and Exploration Companies, The Pastoralists and Graziers Association of W.A. (1999) Code of conduct for mineral exploration on pastoral leases. Perth, Australia, pp. 1-10

Therivel R, Ross B (2007) Cumulative effects assessment: does scale matter? Environmental Impact Assessment Review 27(5):365-385

Tyler NJ, Stokkan KA, Hogg CR, Nellemann C, Vistnes AI (2016) Cryptic impact: Visual detection of corona light and avoidance of power lines by reindeer. Wildlife Society Bulletin 40(1):50-58

Underwood EC, Klausmeyer KR, Cox RL, Busby SM, Morrison SA, Shaw MR (2009) Expanding the global network of protected areas to save the imperiled Mediterranean biome. Conservation Biology 23(1):43-52

van der Ree R, Smith DJ, Grilo C (2015a) The ecological effects of linear infrastructure and traffic. In: van der Ree R., Smith D. J., Grilo C. (eds), Handbook of Road Ecology. John Wiley \& Sons, Ltd, Chichester, UK, pp. 1-9 van der Ree R, Smith DJ, Grilo C (eds) (2015b) Handbook of Road Ecology. John Wiley \& Sons, Chichester, UK van Etten EJB (2013) Changes to land tenure and pastoral lease ownership in Western Australia's central rangelands: implications for co-operative, landscape-scale management. The Rangeland Journal 35(1):37-46

Vistnes I, Nellemann C (2001) Avoidance of cabins, roads, and power lines by reindeer during calving. The Journal of wildlife management 65(4):915-925

Watson A, Judd S, Watson J, Lam A, Mackenzie D (2008) The extraordinary nature of the Great Western Woodlands. The Wilderness Society, Perth

Westcott F, Andrew ME (2015) Spatial and environmental patterns of off-road vehicle recreation in a semiarid woodland. Applied Geography 62(0):97-106

Wood EM, Pidgeon AM, Radeloff VC et al (2014) Housing development erodes avian community structure in U.S. protected areas. Ecol Appl 24(6):1445-1462

Zuur A, leno EN, Walker N, Saveliev AA, Smith GM (2009) Mixed effects models and extensions in ecology with R. Springer Science \& Business Media 


\section{Supplementary material: Appendices}

\section{Appendix 1: Patch-level predictors of development footprint}

This appendix provides further information on the patch-level analysis of development drivers. We divided sample areas into 1352 patches, comprising 261 polygonal 'patch types', each with a unique combination of categorical variable levels, and then calculated values for a range of numerical variables (Table A1.1; Figure A1.1). We calculated area and development footprint for each patch type, and modelled the development footprint proportion (logit-transformed) of each patch type using linear mixed models with ' $n$ Ime' package in R. Random effects in the models were specified by sample area. All variables in the final model had $p$ values lower than 0.01 . As patches and patch types varied in size and this could have skewed the calculation of numerical, area-based data; we created centroids for each patch type, constrained to fall within the features they represent, and calculated the relevant information based on the centroids.

Table A1.1: Variables considered as potential predictors of development footprint

\begin{tabular}{|c|c|c|c|}
\hline Variable (code) & source layer & source & levels / transformation \\
\hline $\begin{array}{l}\text { Pastoral tenure } \\
\text { (pastoral/grazed) }\end{array}$ & 'Cadastre' & Landgate & grazed / ungrazed \\
\hline $\begin{array}{l}\text { Greenstone lithology } \\
\text { (greenstone) and iron } \\
\text { formation (iron-form) }\end{array}$ & $\begin{array}{l}\text { 'Geology Bedrock } \\
500 K^{\prime}\end{array}$ & Landgate & $\begin{array}{l}\text { adapted from source layer: greenstone / } \\
\text { not greenstone and iron formation /not } \\
\text { iron formation }\end{array}$ \\
\hline $\begin{array}{l}\text { Conservation tenure } \\
\text { (cons_tenure) }\end{array}$ & $\begin{array}{l}\text { 'DPAW Managed } \\
\text { Lands \& Waters' }\end{array}$ & $\begin{array}{l}\text { Department of } \\
\text { Parks and Wildlife }\end{array}$ & $\begin{array}{l}\text { grouped from source layer: class } A \text {, } \\
\text { gazetted conservation, unofficial } \\
\text { conservation tenure, former leasehold, or } \\
\text { not conservation tenure }\end{array}$ \\
\hline $\begin{array}{l}\text { Schedule } 1 \text { area } \\
\text { clearing restrictions } \\
\text { (schd-1) }\end{array}$ & $\begin{array}{l}\text { 'Clearing Regulations } \\
\text { - Schedule One Areas' }\end{array}$ & $\begin{array}{l}\text { Department of } \\
\text { Environmental } \\
\text { Regulation }\end{array}$ & schedule 1 or not schedule 1 \\
\hline $\begin{array}{l}\text { Environmentally } \\
\text { sensitive area (esa) }\end{array}$ & $\begin{array}{l}\text { 'Clearing Regulations } \\
\text { - Environmentally } \\
\text { Sensitive Areas' }\end{array}$ & $\begin{array}{l}\text { Department of } \\
\text { Environmental } \\
\text { Regulation }\end{array}$ & binary variable \\
\hline $\begin{array}{l}\text { Vegetation formation } \\
\text { (veg_form) }\end{array}$ & $\begin{array}{l}\text { 'Pre-European } \\
\text { Vegetation' }\end{array}$ & $\begin{array}{l}\text { Department of } \\
\text { Parks and Wildlife }\end{array}$ & $\begin{array}{l}\text { grouped from source layer: bare-rock-lake, } \\
\text { broombush thicket, mallee, mulga, } \\
\text { shrubland, succulent steppe, woodland }\end{array}$ \\
\hline Mine project density & MINEDEX & $\begin{array}{l}\text { Department of } \\
\text { Mines and } \\
\text { Petroleum (DMP) }\end{array}$ & log-transformed after adding 1 \\
\hline $\begin{array}{l}\text { Tenement duration } \\
\text { (Intyrs) }\end{array}$ & $\begin{array}{l}\text { Dead Tenements and } \\
\text { Current Tenements }\end{array}$ & DMP & $\begin{array}{l}\text { total duration of dead and current } \\
\text { tenements (end date capped at date of } \\
\text { data extraction) was calculated and log- } \\
\text { transformed; calculated as per centroid of } \\
\text { each 'patch type'. }\end{array}$ \\
\hline $\begin{array}{l}\text { Tenement types } \\
\text { (type) }\end{array}$ & $\begin{array}{l}\text { Tenements and } \\
\text { Current Tenements }\end{array}$ & DMP & $\begin{array}{l}\text { exploration/prospecting tenement, mining } \\
\text { and related activities tenement, none. } \\
\text { Mining tenements overrode exploration } \\
\text { tenements. }\end{array}$ \\
\hline $\begin{array}{l}\text { Primary commodity } \\
\text { (commodity) }\end{array}$ & MINEDEX & DMP & gold, nickel / iron-ore / other / none. \\
\hline $\begin{array}{l}\text { Distance to edge of } \\
\text { wheatbelt }(\mathrm{km}) \\
\text { (wbkm) }\end{array}$ & $\begin{array}{l}\text { Great Western } \\
\text { Woodlands Boundary }\end{array}$ & GondwanaLink & $\begin{array}{l}\text { South-west extent of GWW boundary used } \\
\text { as indicator of wheatbelt edge. Calculated } \\
\text { as at centroid of each 'patch type. }\end{array}$ \\
\hline $\begin{array}{l}\text { Distance to nearest } \\
\text { town }(\mathrm{km}) \text {, } \\
\text { (tnkm) }\end{array}$ & Townsites & Landgate & $\begin{array}{l}\text { Abandoned towns excluded from analysis. } \\
\text { Calculated as at centroid of each 'patch } \\
\text { type'. }\end{array}$ \\
\hline
\end{tabular}



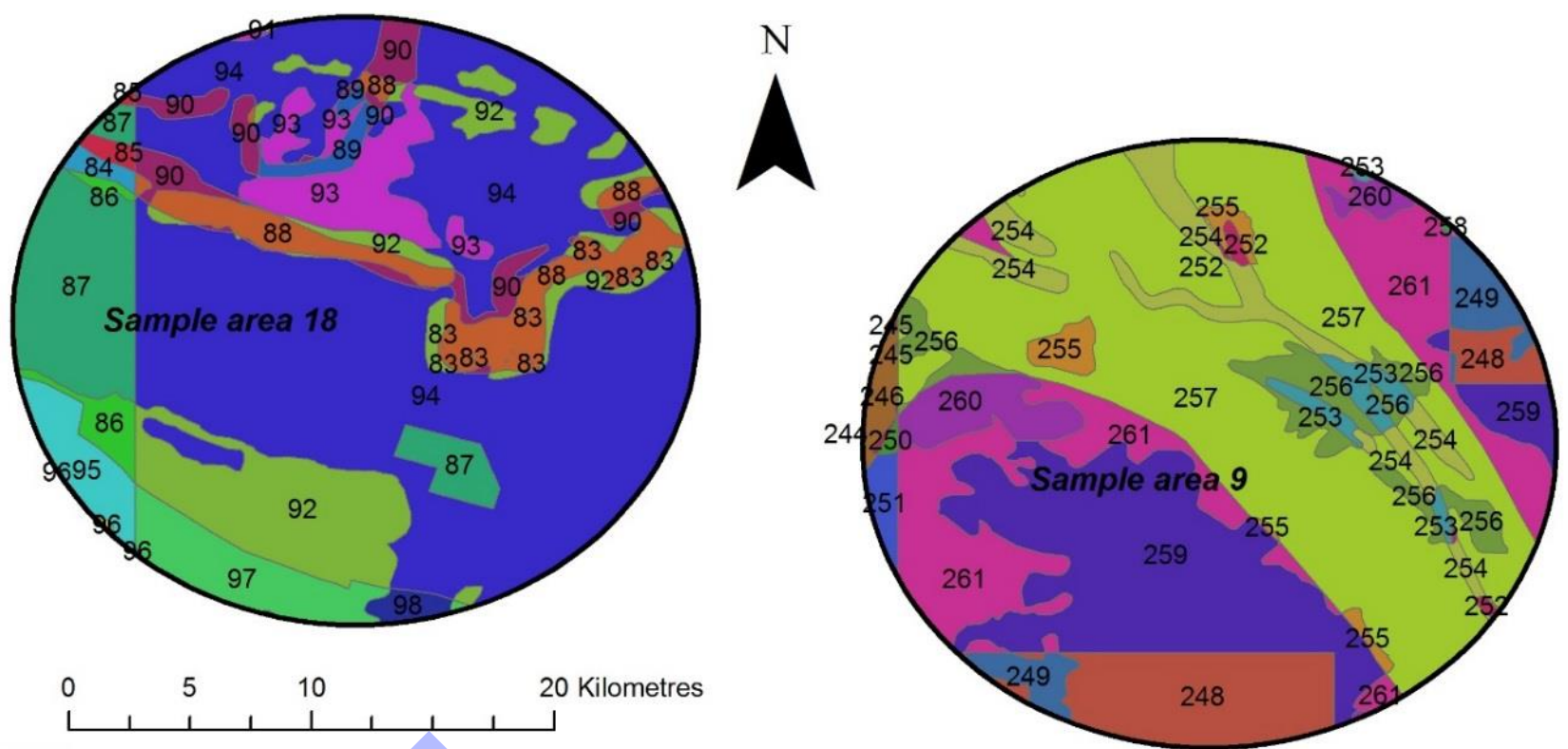

083: SA18, ungrazed, greenstone, ESA, unofficial-cons, iron-form, Sched-1, broombush

084: SA18, ungrazed, greenstone, not-ESA, not-cons-est, iron-form, not_schd_1, broombush

085: SA18, ungrazed, greenstone, not-ESA, not-cons-est, iron-form, not_schd_1, woodland

086: SA18, ungrazed, greenstone, not-ESA, not-cons-est, not-ironstn, not-schd-1, broombush

087: SA18, ungrazed, greenstone, not-ESA, not-cons-est, not-ironstn, not-schd-1, woodland

088: SA18, ungrazed, greenstone, not-ESA, unofficial-cons, iron-form, Sched-1, broombush

089: SA18, ungrazed, greenstone, not-ESA, unofficial-cons, iron-form, Sched-1, shrubland

090: SA18, ungrazed, greenstone, not-ESA, unofficial-cons, iron-form, Sched-1, woodland

092: SA18, ungrazed, greenstone, not-ESA, unofficial-cons, not-ironstone, Sched-1, broombush

093: SA18, ungrazed, greenstone, not-ESA, unofficial-cons, not-ironstone, Sched-1, shrubland

094: SA18, ungrazed, greenstone, not-ESA, unofficial-cons, not-ironstone, Sched-1, woodland

095: SA18, ungrazed, not_greenstone, not-ESA, not-cons-est, not-ironstn, not-schd-1, broombush

096: SA18, ungrazed, not_greenstone, not-ESA, not-cons-est, not-ironstn, not-schd-1, woodland

097: SA18, ungrazed, not_greenstone, not-ESA, unofficial-cons, not-ironstn, Sched-1, broombush

098: SA18, ungrazed, not_greenstone, not-ESA, unofficial-cons, not-ironstn, Sched-1, woodland

244: SA9, ungrazed, greenstone, not-ESA, unofficial-cons, not-ironstn, Sched-1, broombush

245: SA9, ungrazed, greenstone, not-ESA, unofficial-cons, not-ironstn, Sched-1, shrubland

246: SA9, ungrazed, greenstone, not-ESA, unofficial-cons, not-ironstn, Sched-1, woodland

247: SA9, ungrazed, not_greenstone, not-ESA, not-cons-est, not-ironstn, not-schd-1, bare (rock/lake)

248: SA9, ungrazed, not_greenstone, not-ESA, not-cons-est, not-ironstn, not-schd-1, broombush

249: SA9, ungrazed, not_greenstone, not-ESA, not-cons-est, not-ironstn, not-schd-1, woodland

250: SA9, ungrazed, not_greenstone, not-ESA, unofficial-cons, not-ironstn, Sched-1, shrubland

251: SA9, ungrazed, not_greenstone, not-ESA, unofficial-cons, not-ironstn, Sched-1, woodland

252: SA9, pastoral, greenstone, not-ESA, former-leasehold, iron-form, Sched-1, broombush

253: SA9, pastoral, greenstone, not-ESA, former-leasehold, iron-form, Sched-1, shrubland

254: SA9, pastoral, greenstone, not-ESA, former-leasehold, iron-form, Sched-1, woodland

255: SA9, pastoral, greenstone, not-ESA, former-leasehold, not-ironstn, Sched-1, broombush

256: SA9, pastoral, greenstone, not-ESA, former-leasehold, not-ironstn, Sched-1, shrubland

257: SA9, pastoral, greenstone, not-ESA, former-leasehold, not-ironstn, Sched-1, woodland

258: SA9, pastoral, not_greenstone, not-ESA, former-leasehold, not-ironstn, Sched-1, bare (rock/lake)

259: SA9, pastoral, not_greenstone, not-ESA, former-leasehold, not-ironstn, Sched-1, broombush

260: SA9, pastoral, not_greenstone, not-ESA, former-leasehold, not-ironstn, Sched-1, shrubland

261: SA9, pastoral, not_greenstone, not-ESA, former-leasehold, not-ironstn, Sched-1, woodland

Figure A1.1: Example of polygons constructed to assess predictors of development footprint at the patch level 


\section{Appendix 2: Mapped versus unmapped track width comparison}

Mapped and unmapped track widths were measured using high-resolution aerial imagery at at least 20 randomly-generated locations within each of 24 sample areas. We used a t-test to test for a difference between mapped and unmapped track width, conducted data exploration as per (Zuur et al. 2009), and modelled track widths using linear mixed models with 'Ime4' package in R. We created a global model containing the following fixed variables: mapped/unmapped status; mining activity level for the relevant sample area, and pastoral status. Sample area identity was included as the random effect in all models after testing for its significance.

We used the 'dredge' function in 'MuMin' package to model all possible subsets of the global model and rank them based on AICC values. Table A2.1 shows the two top-ranking models, defined as having an AICC within 2 of the optimal model. The optimal model included only mapped/unmapped status as a fixed effect, and the other top-ranking model also included a positive effect of pastoral tenure on track width. Mapped tracks were found to be on average $\sim 1 \mathrm{~m}$ wider than unmapped tracks $(p<0.001)$ (Figure A2.1). Average widths of mapped and unmapped tracks were $6.06 \mathrm{~m}$ (s.e. $0.15 \mathrm{~m}$ ) and $4.92 \mathrm{~m}$ (s.e. $0.10 \mathrm{~m}$ ) respectively. No effect of mining activity was included in the top-ranking models.

Table A2.1 The top-ranking models for track width. The most parsimonious (i.e. optimal) model is shown in bold.

\begin{tabular}{llllll}
\hline $\begin{array}{l}\text { Response } \\
\text { variable }\end{array}$ & $\begin{array}{l}\text { Intercept } \\
\text { (standard } \\
\text { error) }\end{array}$ & $\begin{array}{l}\text { Track } \\
\text { classification } \\
\text { mean } \\
\text { estimated } \\
\text { effect } \\
\text { (unmapped) }\end{array}$ & $\begin{array}{l}\text { Pastoral } \\
\text { status mean } \\
\text { estimated } \\
\text { effect } \\
\text { (ungrazed) }\end{array}$ & AICc & A AICc \\
& & & & \\
\hline $\begin{array}{l}\text { Track width } \\
(\mathbf{m})\end{array}$ & $\mathbf{6 . 0 1 9 ( \mathbf { 0 . 3 0 0 } )}$ & $\mathbf{- 1 . 0 0 7 ( \mathbf { 0 . 1 6 1 } )}$ & - & $\mathbf{5 2 6 1 . 6}$ & $\mathbf{0}$ \\
$\begin{array}{l}\text { Track width } \\
(\mathrm{m})\end{array}$ & $6.310(0.408)$ & $-1.002(0.161)$ & $-0.597(0.569)$ & 5261.8 & 0.21 \\
\hline & & & & & \\
& & & & & \\
\end{tabular}




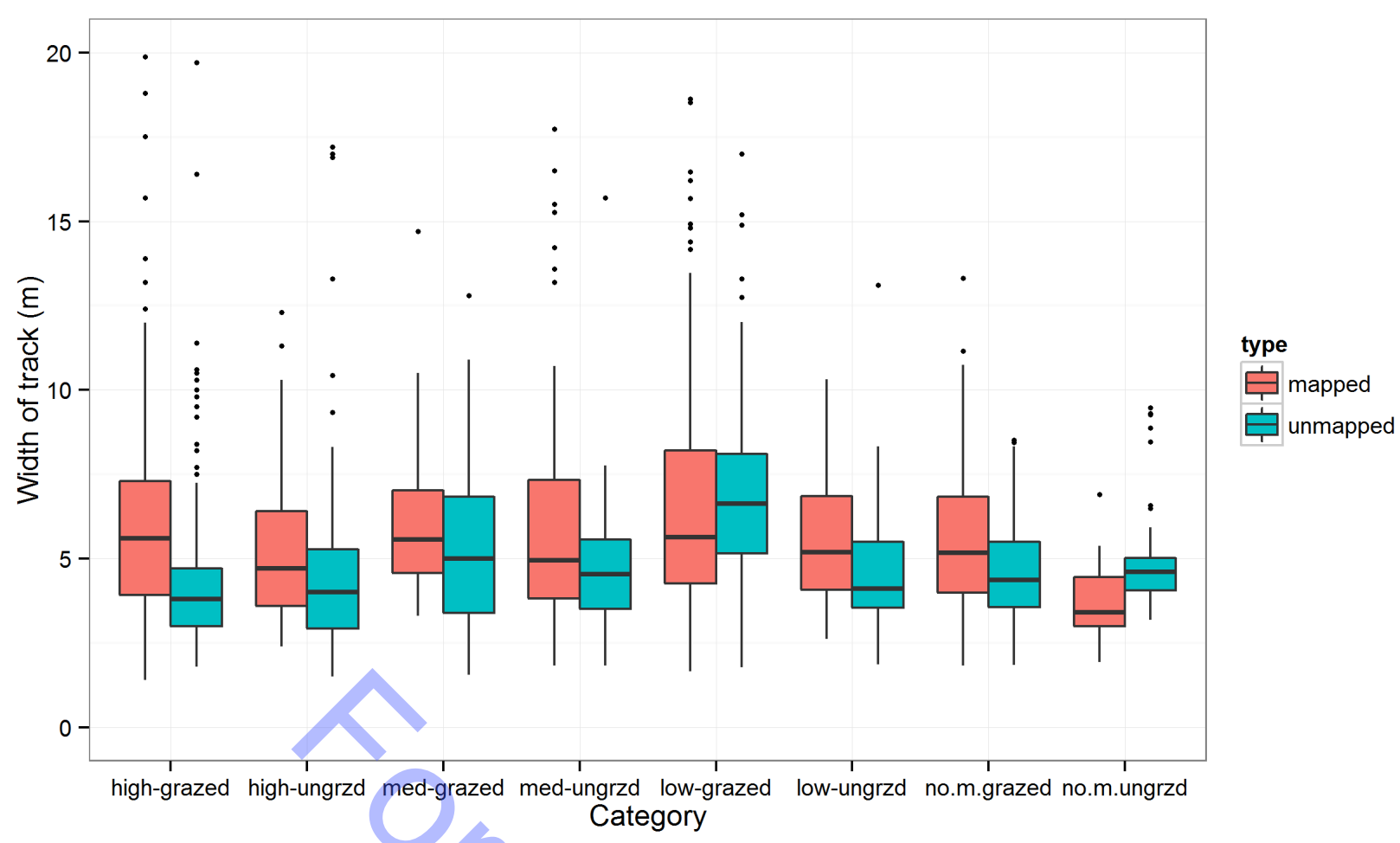

Figure A2.1 Boxplots showing the variation in widths between mapped and unmapped tracks across the different analysis categories for the optimal model. Category names refer to level of mining activity (high, medium, or low density of mining projects, or no mines (no.m)), and pastoral status (grazed or ungrazed). Boxplot centrelines indicate medians and coloured boxes show interquartile range. The whiskers (vertical black lines) extend from the interquartile range to the highest and lowest values that are within 1.5 times the interquartile range, and the points indicate outliers. 


\section{Appendix 3: Hypothesised zones of edge effect risk}

Hypothetical edge effect zones were created, based on effect zones gleaned from the literature and arranged under three scenarios, to reflect potential risks of offsite impacts in areas adjacent to development footprints observed (Table A3.1). The proportion of sample areas that lies within these zones was also calculated, by mining activity and scenario (Figure. A3.1).

Table A3.1 Buffer distances and sources used for calculating edge effect risks

\begin{tabular}{|c|c|c|c|}
\hline \multirow[b]{2}{*}{ Infrastructure type } & \multicolumn{3}{|c|}{ Ecological effect zones $(\mathrm{m})$ with literature sources shown in parentheses } \\
\hline & conservative scenario & moderate scenario & maximal scenario \\
\hline $\begin{array}{l}\text { hub infrastructure } \\
\text { e.g. mine pits, } \\
\text { waste-rock dumps, } \\
\text { dams, homesteads } \\
\text { and mine worker } \\
\text { camps }\end{array}$ & $\begin{array}{l}500 \text { ( } 50 \% \text { of effect on birds } \\
\text { found at this distance from } \\
\text { infrastructure (Benítez-López et } \\
\text { al. 2010); effects of oil roads on } \\
\text { anurans detectable to this } \\
\text { distance (McCracken and } \\
\text { Forstner 2014); slightly above } \\
\text { upper bound of effects observed } \\
\text { by Kasworm and Manley (1990). }\end{array}$ & $\begin{array}{l}\text { 2,000 (half of zone } \\
\text { observed by Vistnes and } \\
\text { Nellerman, } 50 \% \text { of effect } \\
\text { on mammals found at this } \\
\text { distance from } \\
\text { infrastructure and } 7 \text { studies } \\
\text { on birds reported effects to } \\
\text { at least this distance on } \\
\text { birds, Benitez-Lopez et al } \\
\text { 2010), less than the } 3 \mathrm{~km} \\
\text { zone observed by Mahoney } \\
\text { and Schaefer (2002)) }\end{array}$ & $\begin{array}{l}6,000 \text { ( } 50 \% \text { reduction in } \\
\text { habitat effectiveness up } \\
\text { to this distance, Johnson } \\
\text { et al } 2005 ; 16 \text { studies } \\
\text { assessed by Benítez- } \\
\text { López et al. (2010) } \\
\text { reported effect zones of } \\
\text { at least } 6 \text { km for some } \\
\text { mammals) }\end{array}$ \\
\hline $\begin{array}{l}\text { railways } \& \text { all paved } \\
\text { roads }\end{array}$ & $\begin{array}{l}500 \text { (as above, and also in the } \\
\text { lower part of the range of road } \\
\text { effect zones identified for } \\
\text { anurans by Eigenbrod et al. } \\
\text { (2009) }\end{array}$ & $\begin{array}{l}\text { 1,000 (as per Liu et al } \\
\text { (2008), Kasworm and } \\
\text { Manley (1990), and } \\
\text { Johnson et al. (2005), and } \\
\text { as for birds in Benitez- } \\
\text { Lopez et al. (2010), and } \\
\text { anurans in Eigenbrod et al. } \\
\text { (2009) }\end{array}$ & $\begin{array}{l}6,000 \text { (as per Benítez- } \\
\text { López et al. (2010) on } \\
\text { mammals \& Mattson et } \\
\text { al. (1987) for grizzly } \\
\text { bears) }\end{array}$ \\
\hline unpaved roads & $\begin{array}{l}50 \text { (median of shortest distance } \\
\text { for which there was }>50 \% \text { effect } \\
\text { size for both mammals and birds; } \\
\text { Benitez-Lopez (2010)) }\end{array}$ & $\begin{array}{l}250 \text { (as per Liu et al. (2008) } \\
\& \text { Czech (1991)) }\end{array}$ & $\begin{array}{l}2,000 \text { (Suring et al. } \\
\text { (1998) hypothesised 1.6- } \\
3.2 \mathrm{~km} \text { effect for low-use } \\
\text { roads where there is } \\
\text { vegetation cover; half } \\
\text { that found by Vistnes } \\
\text { and Nellemann (2001)). }\end{array}$ \\
\hline mapped tracks & $\begin{array}{l}10 \text { (lower bound of effect zone } \\
\text { around trails observed by } \\
\text { Kasworm and Manley (1990)) }\end{array}$ & 50 (as per Liu et al. (2008)) & $\begin{array}{l}500 \text { ( } 50 \% \text { of effect on } \\
\text { birds found at this } \\
\text { distance from } \\
\text { infrastructure (Benítez- } \\
\text { López et al. 2010); } \\
\text { effects of oil roads on } \\
\text { anurans detectable to } \\
\text { this distance (McCracken } \\
\text { and Forstner 2014); } \\
\text { slightly above upper } \\
\text { bound of effects } \\
\text { observed by Kasworm } \\
\text { and Manley (1990). }\end{array}$ \\
\hline unmapped tracks & 10 (as above) & 50 (as above) & 500 (as above) \\
\hline
\end{tabular}




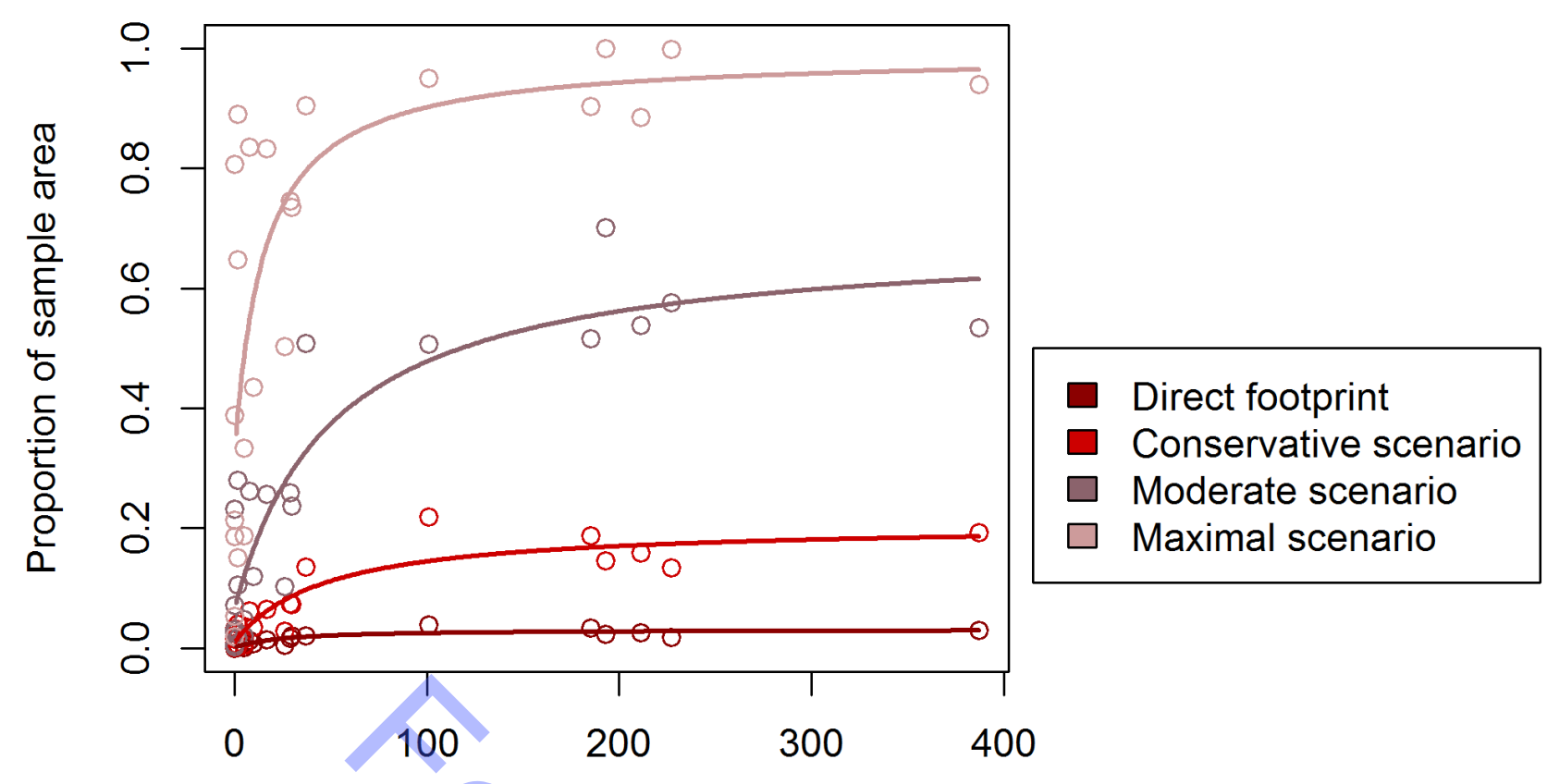

Number of mining projects in sample area

Figure A3.1: Proportion of sample areas within edge effect zones, by mining activity, based on conservative, moderate and maximal scenarios of edge effect extent, derived from literature sources. The lines represent hyperbolic fits.

It is important to note that Figure A3.1 is intended only to demonstrate the cumulative effects of off-site impacts, which can dwarf on-site impacts in extent, although often not in intensity. The existence of an edge effect zone over an area does not mean that all ecological values are completely destroyed within that area. Hence, impacts are likely to accumulate with increasing mining activity, long after unaffected areas have disappeared from a landscape. For example, an area similar in size to the sample areas with 400 mines is expected to have its ecological values more degraded than a similar-sized area with 100 mines, even though the edge effect zone in both cases has almost saturated both areas under the maximal scenario. All other things being equal, however, the difference between the impacts in an area with one mine and an area with 51 mines is likely to be far greater than between an equally-sized area with 201 mines and an area with 251 mines. 